


\section{De bepaling van diersoorten in vleesmengsels met DNA-gebaseerde qPCR-methoden}

A. Aartse, I.M.J. Scholtens, E.J. Kok

Dit onderzoek is uitgevoerd door RIKILT Wageningen University \& Research, instituut binnen de rechtspersoon Stichting Wageningen Research in opdracht van en gefinancierd door de Algemene Kokswaren en Snackproducten Vereniging, Louis Braillelaan 80, 2719 EK, Zoetermeer.

Wageningen, december 2017

RIKILT-rapport 2017.009 
Aartse, A., Scholtens, I.M.J., Kok, E.J., 2017. De bepaling van diersoorten in vleesmengsels met DNAgebaseerde qPCR-methoden. Wageningen, RIKILT Wageningen University \& Research, RIKILT-rapport 2017.009. 34 blz.; 6 fig.; 10 tab.; 18 ref.

Projectnummer: 1267348701

Projecttitel: Detectie paardenvlees in rundvlees

Projectleider: dr.ir. E.J. Kok

Dit rapport is gratis te downloaden op https://doi.org/10.18174/428145 of op www.wur.nl/rikilt (onder RIKILT publicaties).

(C) 2017 RIKILT Wageningen University \& Research, instituut binnen de rechtspersoon Stichting Wageningen Research. Hierna te noemen RIKILT.

Het is de opdrachtgever toegestaan dit rapport integraal openbaar te maken en ter inzage te geven aan derden. Zonder voorafgaande schriftelijke toestemming van het RIKILT is het niet toegestaan:

a. dit door RIKILT uitgebrachte rapport gedeeltelijk te publiceren of op andere wijze gedeeltelijk openbaar te maken;

b. dit door RIKILT uitgebrachte rapport, c.q. de naam van het rapport of RIKILT, geheel of gedeeltelijk te doen gebruiken ten behoeve van het instellen van claims, voor het voeren van gerechtelijke procedures, voor reclame of antireclame en ten behoeve van werving in meer algemene zin;

c. de naam van RIKILT te gebruiken in andere zin dan als auteur van dit rapport.

Postbus 230, 6700 AE Wageningen, T 03174802 56, E info.rikilt@wur.nl, www.wur.nl/rikilt. RIKILT is onderdeel van Wageningen University \& Research.

RIKILT aanvaardt geen aansprakelijkheid voor eventuele schade voortvloeiend uit het gebruik van de resultaten van dit onderzoek of de toepassing van de adviezen.

RIKILT-rapport 2017.009

Verzendlijst:

- mw. Karin Koppen, beleidsmedewerker AKSV, Postbus 64, 2700 AB Zoetermeer, Karin.Koppen@COV.nI

- dhr. Richard van der Kruijk, secretaris AKSV, Postbus 64, 2700 AB Zoetermeer, RvdKruijk@COV.nl 


\section{Inhoud}

$\begin{array}{ll}\text { Samenvatting } & \mathbf{5}\end{array}$

1

Basisprincipes van kwalitatieve en semi-kwantitatieve detectiemethoden $\quad 7$

$\begin{array}{lll}1.1 & \text { Bemonsteren van het te testen product } & 7\end{array}$

1.2 GPCR: de detectiemethode $\quad 8$

$\begin{array}{lll}1.3 & \text { De essentie van semi-kwantitatieve bepaling } & 11\end{array}$

1.4 DNA: het startmateriaal $\quad 12$

1.5 Singleplex en multiplex qPCR-testen 12

2.1 Matrix effect 13

2.2 Voor- en nadelen van mitochondriële en nucleaire qPCR-testen 14

2.3 Voor- en nadelen van singleplex en multiplex qPCR-testen $\quad 15$

2.4 Verschillende detectiemethoden; de data-interpretatie $\quad 15$

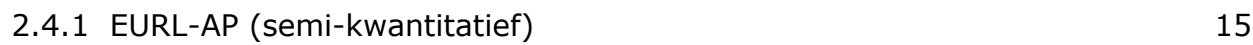

2.4.2 RapidFinder1 (semi-kwantitatief) 16

2.4.3 Nixon et al. (semi-kwantitatief) 16

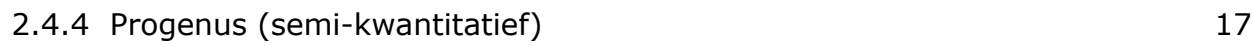

$\begin{array}{ll}2.4 .5 \text { Genesig (semi-kwantitatief) } & 17\end{array}$

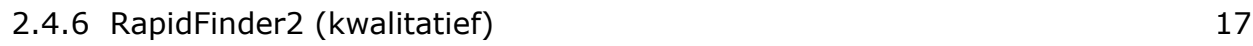

$\begin{array}{lll}2.5 & \text { Conclusie } & 18\end{array}$

3 Introductie op de praktische vergelijking van een aantal methoden voor de detectie van paardenvlees

$4.1 \quad$ Vleesmengsels $\quad 20$

$\begin{array}{lll}4.2 & \text { DNA isolatie } & 20\end{array}$

$\begin{array}{lll}4.3 & \text { Detectiemethoden } & 20\end{array}$

4.3.1 EURL-AP referentiemethode (semi-kwantitatief) 21

$\begin{array}{ll}\text { 4.3.2 RapidFinder1 (semi-kwantitatief) } & 21\end{array}$

4.3.3 Nixon et al. (semi-kwantitatief) 22

4.3.4 Progenus (semi-kwantitatief) $\quad 22$

4.3.5 Genesig (semi-kwantitatief) 23

4.3.6 RapidFinder2 (kwalitatief) 24

$5 \quad$ Resultaten praktische vergelijking $\quad 25$

$6 \quad$ Discussie en conclusie praktische vergelijking $\quad 28$

7 Voorbeelden van factoren die de uitslag van een DNA test kunnen $\begin{array}{ll}\text { beïnvloeden } & \mathbf{3 0}\end{array}$

$\begin{array}{ll}\text { Literatuur } & \mathbf{3 1}\end{array}$

$\begin{array}{lll}\text { Bijlage } 1 & \text { Uitgebreide uitleg qPCR } & 32\end{array}$ 



\section{Samenvatting}

\section{Algemeen}

In de voedselindustrie is het belangrijk om te weten hoeveel van een bepaalde component aanwezig is in een product. Zoals bijvoorbeeld hoeveel procent kip, varken, koe of paard er in een snackproduct zit. Mede omdat er in richtlijn 2000/13/EG staat dat de consument niet misleid mag worden ten aanzien van de kenmerken van het levensmiddel, onder andere de oorsprong of herkomst, samenstelling en hoeveelheid. Voor levensmiddelen die vlees als ingrediënt bevatten wordt er in aanbeveling 2013/99/EU vermeld dat de diersoort waarvan het vlees afkomstig is, vermeld moet staan op het etiket. En als de diersoort op het etiket vermeld staat, moet ook worden vermeld hoeveel er aanwezig is, uitgedrukt in procenten. In aanbeveling 2014/180/EU staat beschreven dat de eerste screeningsmethode minimaal 0,5\% paardenvlees aan moet kunnen tonen. Verschillende bedrijven bieden detectiekits op basis van DNA aan waarmee door laboratoria het percentage bepaald kan worden van bepaalde diersoorten in een product (kwantificering) om zo bijvoorbeeld de eerste screening uit te voeren. Er zijn echter veel factoren die een rol spelen bij het kwantificeren die niet altijd bekend zijn of duidelijk verwoord zijn. Daardoor ontstaan misvattingen en verwarring over de betrouwbaarheid van de kwantificering van een bepaalde diersoort.

\section{Onderzoek}

Om een duidelijker beeld te geven van een aantal van deze beschikbare detectiekits wordt er in dit rapport een evaluatie gegeven van de basisprincipes van de detectiemethoden. Deze detectiemethoden zijn allen gebaseerd op DNA en maken gebruik van de techniek 'quantitative Polymerase Chain Reaction' (qPCR). Hoewel deze methoden kwantitatief worden genoemd, zullen ze in dit rapport geclassificeerd worden als semi-kwantitatief. Semi-kwantitatieve resultaten geven aan of een resultaat boven of beneden een grenswaarde ligt. Een voorbeeld van een semi-kwantitatieve methode is de EURL-AP referentiemethode. Deze methode maakt gebruik van een $1 \%$ paardenvleesin-rundvleesmengsel dat als grens gehanteerd wordt. Wanneer deze grens overschreden wordt, wordt het monster gerapporteerd als "de $1 \%$ massafractie paardenvlees overschreden". Over het percentage paardenvlees in het monster worden verder echter geen uitspraken gedaan. Naast semi-kwantitatieve testen zijn er ook kwalitatieve testen commercieel verkrijgbaar. Met deze testen kan de aanwezigheid van een bepaalde diersoort aangetoond worden. In tegenstelling tot semi-kwantitatieve testen wordt er in kwalitatieve testen echter geen informatie gegenereerd ten aanzien van de mate waarin de geanalyseerde diersoort aanwezig is.

Ook al is de essentie van de detectiemethoden hetzelfde (op DNA-gebaseerde qPCR-testen), de data interpretatie en -analyse zijn verschillend per detectiemethode. Hierdoor worden er verschillen gevonden tussen de methoden en kunnen het berekende percentage en het daadwerkelijke percentage van een product van elkaar verschillen. In het eerste deel van dit rapport (hoofdstukken 1 en 2) wordt de werking van verschillende commercieel verkrijgbare detectiemethoden uitgelegd. Verder wordt ook de referentiemethode van het EURL-AP voor paardenvlees detectie toegelicht. Deze methode voldoet aan de eisen voor een bevestigingstest die genoemd worden in aanbeveling 2014/180/EU en is ontwikkeld voor handhaving van de Europese regelgeving. Tevens wordt in dit eerste deel van het rapport ook het bemonsteren en voorbereiden van het te onderzoeken product kort besproken.

In het tweede gedeelte van het rapport (hoofdstuk 3 ) is de werking en toepasbaarheid van verschillende commercieel verkrijgbare detectiemethoden onderzocht. Er zijn vijf semi-kwantitatieve methoden en één kwalitatieve methode voor de bepaling van (de hoeveelheid) paardenvlees in een bepaald monster in de praktijk getest. Dit is gedaan volgens het protocol van de producent van de methode. Het controleren van de specificiteit van de methodes was geen onderdeel van dit project.

Voor deze analyses zijn er paardenvlees-in-rundvlees-mengsels gemaakt, in verschillende percentages; $10 \%, 1 \%, 0,1 \%$ en daarnaast zijn de positieve en negatieve controles meegenomen, 
$100 \%$ en $0 \%$, respectievelijk. Daarnaast is er ook een mengsel van $1 \%$ paardenvlees in een andere achtergrond dan rundvlees meegenomen in de analyse, namelijk paardenvlees dat gemengd is met een snackproduct. Deze mengsels zijn getest met de verschillende detectiemethoden en de resultaten zijn vergeleken met de European Union Reference Laboratory for Animal Proteins in feedingstuffs (EURL-AP) referentiemethode. Deze referentiemethode voldoet aan de eisen voor de bevestigingsmethode die genoemd worden in aanbeveling 2014/180/EU. Deze methode wordt met name gebruikt door officiële labs voor handhavingsdoeleinden. In deze aanbeveling wordt beschreven dat alle positieve monsters uit de screeningstest, bevestigd moeten worden met een op mitochondrieel DNA gebaseerde qPCR-test. Zoals al eerder beschreven is, maakt de referentiemethode gebruik van een $1 \%$ paardenvlees-in-rundvleesmengsel. Dit mengsel is ter beschikking gesteld aan EU handhavingslaboratoria die gebruik maken van deze methode om zo variatie tussen paardenvleesmengsels te voorkomen bij gebruik van de methode.

\section{Resultaten}

Het is niet mogelijk om het exacte percentage te berekenen van een bepaalde diersoort in een vleesproduct, doordat er veel factoren meespelen die invloed kunnen hebben op de uitslag. Voor mengsels die hetzelfde percentage paardenvlees bevatten maar gemengd met verschillende soorten ander vlees (andere matrix), kan het gevonden percentage fluctueren bij gebruik van dezelfde detectiemethode. De matrix kan dus effect hebben op het uiteindelijk berekende percentage paardenvlees. Tevens heeft de testmethode en de data-analyse invloed op het uiteindelijke resultaat.

In het tweede gedeelte van dit rapport (hoofdstuk 3 tot en met 6) zijn semi-kwantitatieve en kwalitatieve methoden voor de bepaling van het percentage paardenvlees in vleesmengsels vergeleken met de EURL-AP-methode, die is ontwikkeld voor handhaving van de Europese regelgeving. Bij deze vergelijking is gebleken dat de overige methoden vergelijkbare resultaten geven als de EURL-AP-methode, maar dat er verschillen te zien zijn in percentages rondom de $1 \%$. Er zijn geen vals positieve resultaten gevonden met de verschillende methoden op basis van de negatieve monsters. Positieve resultaten zullen dus in de meeste gevallen daadwerkelijk wijzen op vermenging van vleessoorten. In het specifieke geval van de vermenging van paardenvlees in een vleesmengsel kunnen de resultaten (aangetoond dan wel niet aangetoond) verschillen van de EURL-AP-methode wanneer het percentage rond de $1 \%$ ligt, waarbij het erop lijkt dat de overige methoden een beperkte overschatting van het percentage paardenvlees laten zien, maar dit kan op basis van de beperkte serie niet met zekerheid worden vastgesteld.

In het laatste hoofdstuk (7) wordt een samenvatting gegeven van de factoren die de uitslag van een DNA test kunnen beïnvloeden. 


\section{Basisprincipes van kwalitatieve en semi-kwantitatieve detectiemethoden}

Volgens richtlijn 2000/13/EG [2] mag de consument niet misleid worden ten aanzien van de kenmerken van het levensmiddel. Dit wil zeggen dat er op het etiket onder meer vermeld moet worden wat de oorsprong of herkomst is, de samenstelling en de hoeveelheid. Voor levensmiddelen die vlees bevatten, moet volgens aanbeveling 2013/99/EU [3] op het etiket vermeld staan over welke diersoort het gaat en daarnaast ook in welke hoeveelheid deze diersoort verwerkt is in het levensmiddel. Deze hoeveelheid moet uitgedrukt zijn in procenten. Om de aanwezigheid van een bepaalde diersoort aan te tonen, zijn er verschillende detectiekits en -methoden commercieel verkrijgbaar. De detectiemethoden die aan kunnen tonen of er een bepaalde diersoort in een product zit, worden kwalitatieve testen genoemd. Bij deze testen worden er geen hoeveelheden gegeven als resultaat; een ja of nee antwoord is de uiteindelijke beoordeling. De methode van RapidFinder 2 is hier een voorbeeld van. Naast de kwalitatieve testen zijn er ook detectiemethoden waarmee getest kan worden hoeveel er van een bepaalde diersoort in het product zit; dit worden semi-kwantitatieve testen genoemd. Bij deze testen wordt er meestal een percentage van het te onderzoeken diersoort genoemd dat in een bepaald product zit, waaruit opgemaakt kan worden of het percentage boven of beneden een bepaalde drempelwaarde is, bijvoorbeeld van $1 \%$. Zo zijn er semi-kwantitatieve methoden beschikbaar van onder andere de EURL-AP referentiemethode, RapidFinder ${ }^{\mathrm{TM}} 1$ (imegen,

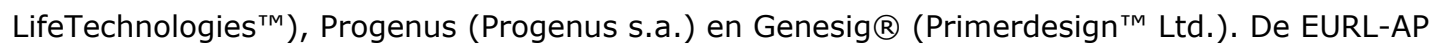
referentiemethode wordt genoemd als richtsnoer in aanbeveling 2014/180/EU [4] als bevestigingsmethode voor de positieve monsters uit de screeningsmethode. Verder zijn er ook een aantal wetenschappelijke artikelen gepubliceerd die methoden beschrijven voor het kwantificeren van bepaalde diersoorten in vleesproducten [5-8]. De methoden zijn in de essentie gelijk aan elkaar; ze zijn op DNA-gebaseerde detectiemethoden, die gebruik maken van de techniek quantitative Polymerase Chain Reaction (qPCR). Toch komen uit de verschillende methoden uiteenlopende resultaten. Dit heeft te maken met de eigenschappen van het DNA, de verschillen in de opbouw van de test, de data interpretatie en de analyse.

In dit hoofdstuk worden de verschillen in test-opbouw, data interpretatie en analyse in zijn algemeenheid beschreven. Met deze achtergrond kennis, worden verschillende beschikbare detectiemethoden geëvalueerd in hoofdstuk 2 .

\subsection{Bemonsteren van het te testen product}

De allereerste stap waar het hele proces mee begint is het bemonsteren van het product. Dit is één van de belangrijkste dingen van het proces. Als er een verwerkt product onderzocht moet worden, dat bestaat uit verschillende diersoorten en stukken vlees, moet dit product eerst goed gemalen en gehomogeniseerd worden. Het homogeniseren is geen gemakkelijke taak; sommige stukken vlees zijn gemakkelijker te vermalen dan anderen [8]. Een voorbeeld waarom homogeniseren van een product van belang is wordt hier beschreven:

Het te onderzoeken product is een kroket. Deze kroket bestaat uit verschillende diersoorten en moet onderzocht worden hoeveel rundvlees er in verwerkt zit. Als er een klein stukje vlees (rund) uit de kroket gehaald wordt, zal de test hoogstwaarschijnlijk een uitslag geven dat de kroket uit $100 \%$ rundvlees bestaat. Maar dit hoeft niet waar te zijn; alleen het kleine stukje vlees is $100 \%$ rund. Om te kunnen zeggen dat de kroket uit $100 \%$ rundvlees bestaat, zal de kroket in zijn geheel gemalen moeten worden en gehomogeniseerd, het liefst in grotere aantallen zoals de hele doos. Zodat elk stukje dat van dit mengsel genomen wordt, hetzelfde resultaat geeft.

Voor diervoeders zijn er strikte regels afgesloten in de wet, bijvoorbeeld verordening (EU) $\mathrm{nr}$. $691 / 2013$ [9] over het bemonsteren en het behandelen van deze monsters. Echter, voor voedingsmiddelen is dit nog een grijs vlak. Wel worden de algemene richtlijnen van bemonstering beschreven op de website van de Warenwetregeling Monsterneming. Het volgende wordt beschreven in paragraaf 1: "In de gevallen waar de grootte van de partij, de wijze van verpakking of de aard der te bemonsteren waar een dergelijke dooreen menging bezwaarlijk maakt, worden van verschillende 
plaatsen der partij voetstoots kleine gedeelten genomen, waaruit het monster wordt samengesteld, of waaruit, na zorgvuldige menging, het monster wordt genomen." Dit kan problemen veroorzaken als er een grote bulk aan gemengd vlees getest moet worden. Zoals het hierboven beschreven voorbeeld van de kroket; de genomen stukjes vlees van de grote bulk zouden geen goede weergave aan percentage kunnen zijn voor het daadwerkelijke samenstelling van de bulk. Op deze wijze kan met name gerapporteerd worden welke diersoorten in de bulk aanwezig zijn.

\section{2 qPCR: de detectiemethode}

De overeenkomst tussen de verschillende detectiemethoden en -kits is dat ze gebaseerd zijn op quantitative Polymerase Chain Reaction; qPCR. qPCR maakt gebruik van het DNA dat aanwezig is in de cel. De qPCR-test wordt uitgevoerd in een qPCR machine; een thermal cycler. In Figuur 1.2.1 is schematische weergave te zien hoe een qPCR-test er in de essentie uitziet. In de reactie zijn verschillende componenten aanwezig, onder andere de primers, de probe, een polymerase (enzym) en nucleotiden (DNA bouwstenen $A, T, C, G$ ). Een qPCR test is opgebouwd uit de volgende stappen:

1. Denaturatie van het DNA, om van dubbelstrengs DNA naar enkelstrengs DNA te gaan,

2. Binding van de primers en probe op een specifiek stukje DNA,

3. Vanuit de primers wordt het DNA verlengd, komt de probe los van DNA en er wordt de fluorescentie gemeten door de thermal cycler.

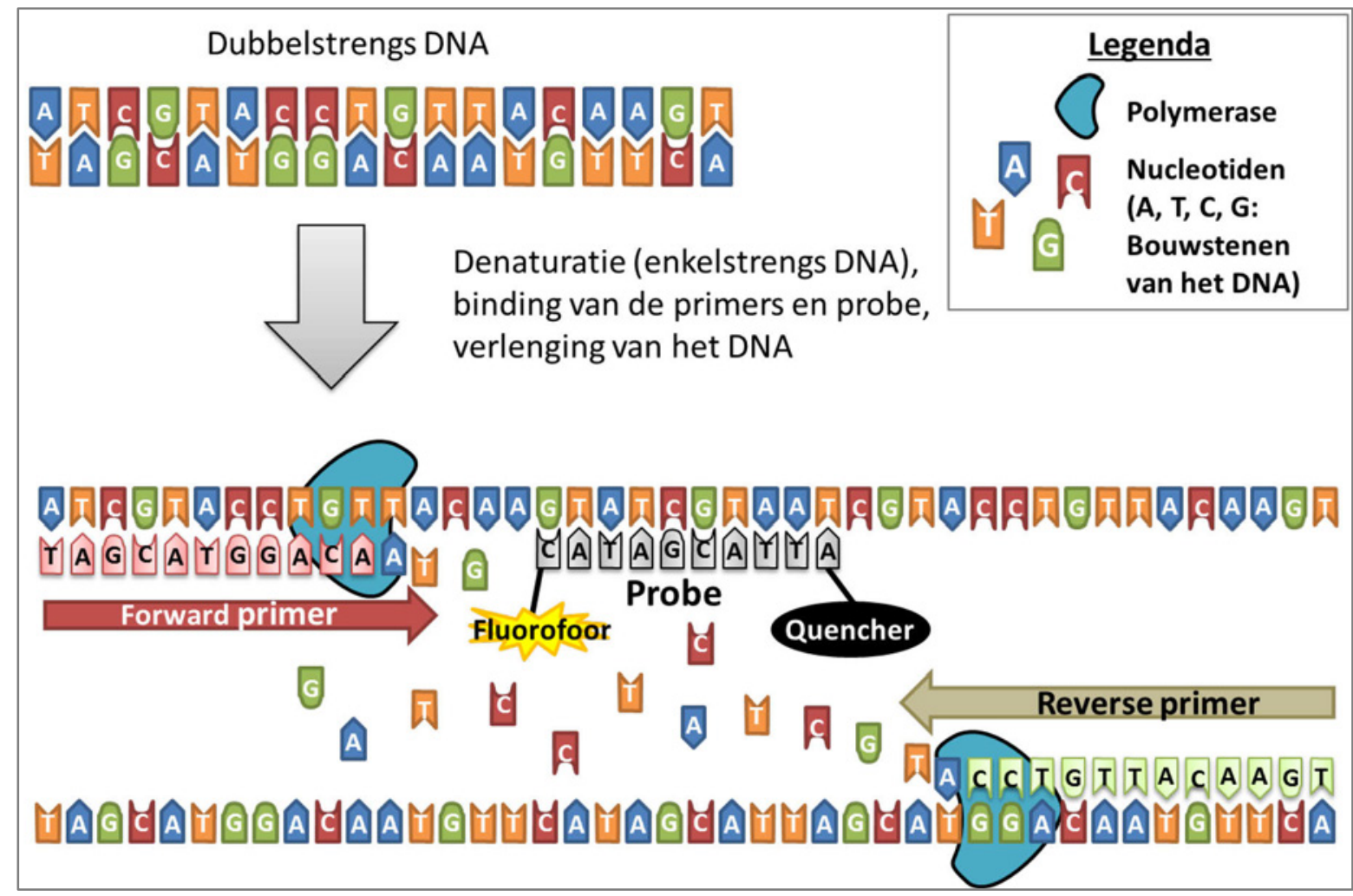

Figuur 1.2.1 Schematische weergave van een qPCR-test; het verdubbelen van een specifiek stukje DNA. De componenten die hierbij betrokken zijn, zijn onder andere: polymerase (enzym), nucleotiden (DNA bouwstenen $A, T, C, G$ ), primers en de probe. Dubbelstrengs DNA wordt eerst enkelstrengs gemaakt (denaturatie), zodat de primers en de probe kunnen binden aan het DNA. Met behulp van de polymerase worden er nucleotiden vanaf de primer toegevoegd en zo wordt het DNA verlengd.

Kenmerkend voor een qPCR-test is dat de drie hierboven beschreven stappen herhaald worden; een cyclus. In elke cyclus worden specifieke stukjes DNA (bijvoorbeeld voor rund) gekopieerd doordat de primers het DNA verlengen. Hierdoor neemt het aantal DNA strengen waaraan de probe kan binden toe en zo komt er bij elke cyclus meer fluorescent signaal vrij (Figuur 1.2.2). In elke cyclus worden de 
specifieke stukjes DNA verdubbeld. Dit proces zorgt ervoor dat de toename van fluorescentie gemonitord kan worden in de thermal cycler. In bijlage 1 is in detail beschreven hoe een qPCR -test precies werkt.

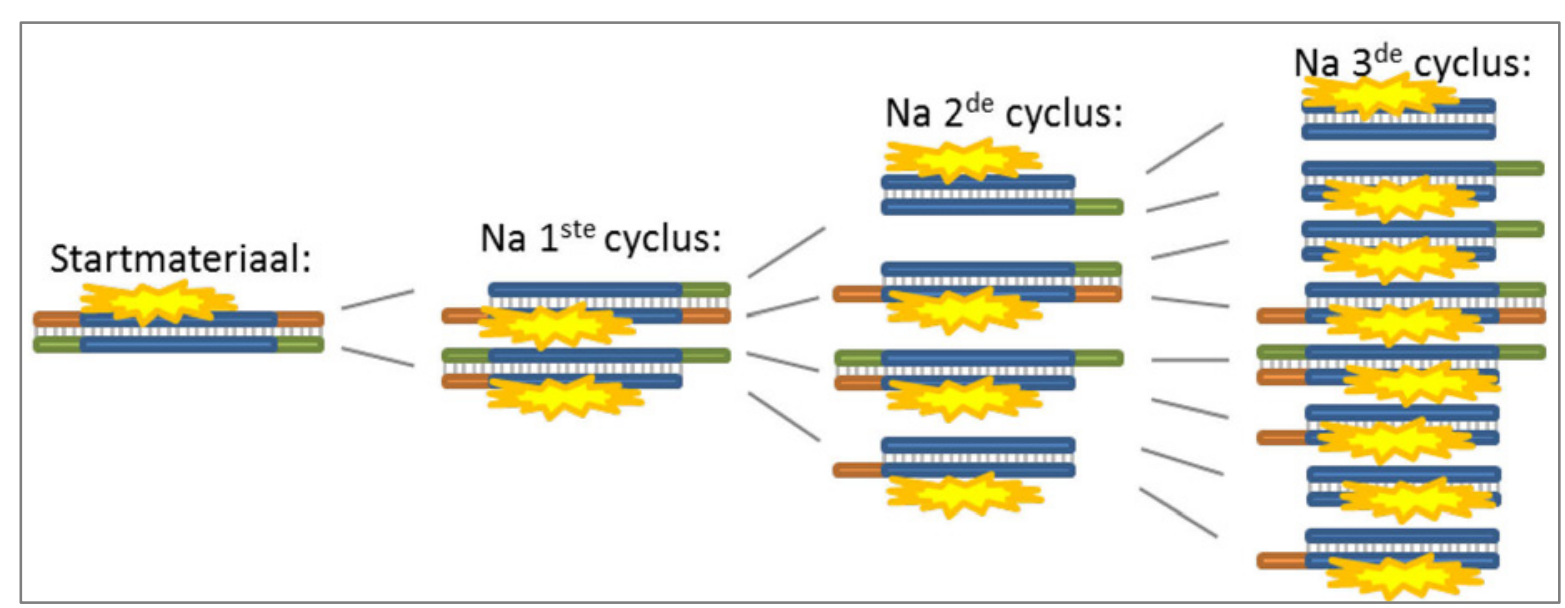

Figuur 1.2.2 Schematisch overzicht hoe het DNA per cyclus verdubbeld wordt en het fluorescente signaal per cyclus toeneemt in een qPCR-test. Deze toename wordt gedetecteerd door de thermal cycler.

\section{De output van een qPCR test}

In Figuur 1.2.3 is een voorbeeld te zien van de output van de thermal cycler. In de grafiek is het aantal cycli uitgezet tegen het fluorescentie signaal RFU (Relative Fluorescence Units). De lijnen die gevormd worden in de grafiek worden amplificatie curven genoemd.

De waarde die wordt toegekend aan een amplificatie curve is de Cq. Deze waarde wordt mede bepaald door de grenslijn (threshold) die gezet wordt. Dit is de blauwe lijn in Figuur 1.2.3; voor het meest betrouwbare resultaat moet de threshold in de eerste bolling van de curve geplaatst zijn. De Cq waarde is het aantal cycli dat nodig is om een fluorescentie signaal (RFU) te krijgen dat de threshold heeft overschreden [10]. Bijvoorbeeld, als er in twee te meten DNA monsters, exact hetzelfde aantal DNA kopieën zouden zitten, zou in theorie de thermal cycler voor beide monsters dezelfde Cq waarde moeten geven. Hoe meer DNA kopieën er in het monster zitten, des te meer kopieën er gevormd kunnen worden per cyclus; en zal de threshold eerder overschreden worden. Dit resulteert in een lagere $\mathrm{Cq}$ waarden, met andere woorden een amplificatie curve wordt gevormd die eerder gedetecteerd wordt. Zo is in Figuur 1.2.3 de oranje lijn een amplificatie curve met een Cq waarde van 24 en de groene lijn een amplificatie curve met een $\mathrm{Cq}$ waarde van 28 . Dit wil zeggen dat er in de oranje amplificatie meer DNA aanwezig is dan in de groene amplificatie. Het verschil in Cq waarden tussen de twee amplificaties is 4 cycli. In theorie, verdubbelt in elke cyclus het aantal DNA strengen dat aanwezig is; daardoor zou in de oranje amplificatie $(2 \times 2 \times 2 \times 2=) 16$ keer meer DNA zitten dan in de groene amplificatie. 


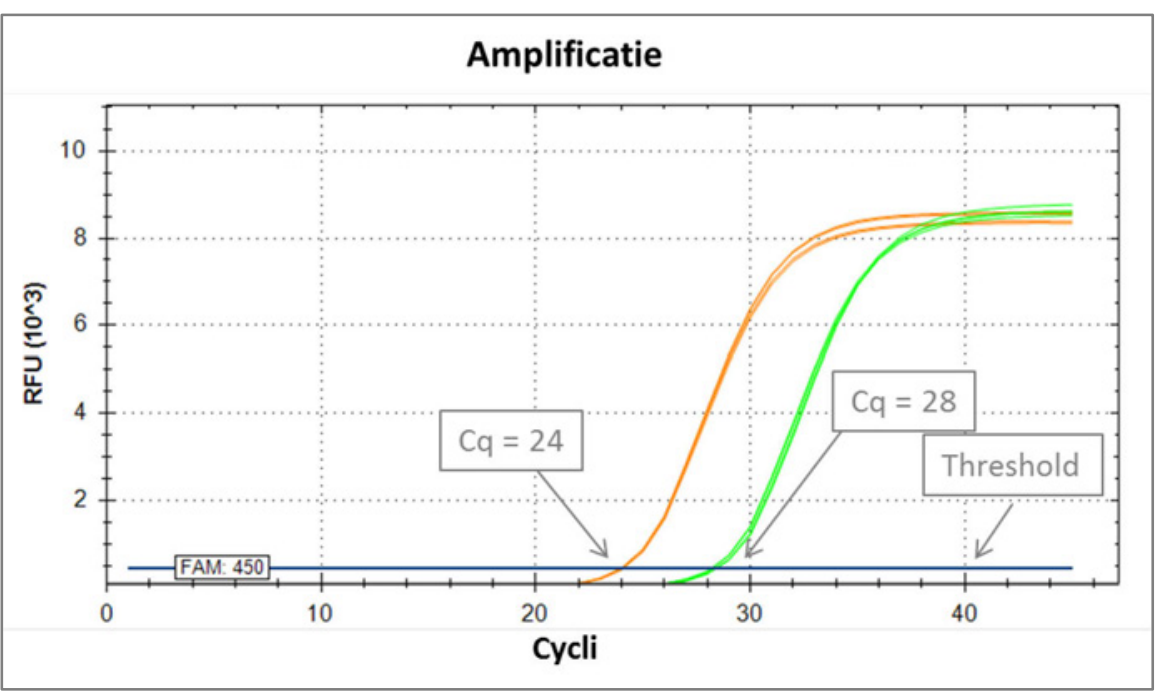

Figuur 1.2.3 De output van een qPCR-test. Het aantal cycli is uitgezet tegen de fluorescentie RFU (Relative Fluorescence Units). De oranje lijn en groene lijn zijn amplificatie curven en hebben respectievelijk een Cq waarden van 24 en 28. De blauwe lijn is de grenslijn (threshold) die in de eerste bolling van de curve neergezet is. Dit komt overeen met een RFU waarde van 450.

\section{Het maken en toepassen van een standaardlijn}

Met behulp van techniek van qPCR is het mogelijk om een standaardlijn te maken. Dit is één van de methoden om te kunnen kwantificeren. De essentie van een standaardlijn is om aan de hand van een bekende factor (bijv. concentratie, kopienummers) een verdunningsreeks te maken met een gelijke verdunningsfactor. Doordat in een qPCR-test per cyclus het DNA verdubbeld wordt, is er een lineair verband tussen het aantal cycli en de bekende factor (concentratie, kopienummers). Een standaardlijn moet voldoen aan bepaalde voorwaarden.

Een voorbeeld ter verduidelijking:

Het aantal kopieën in een DNA monster is 12.500. Dit monster wordt verdund met de constante verdunningsfactor 5 en dit wordt 4 keer gedaan. Zo krijg je de volgende reeks met kopienummers: 12.500 - 2500 - 500 - 100 - 20. Wanneer er een qPCR-test uit wordt gevoerd, zal een soortgelijke amplificatie grafiek ontstaan zoals te zien is in Figuur 1.2.4 A. De verschillende verdunningen zijn aangegeven met nummers 1-5. Waarbij 1 overeenkomt met het hoogste aantal kopieën (12.500) en 5 overeenkomt met het laagste aantal kopieën (20). In Figuur 1.2.4 B is de standaardlijn afgebeeld. De Cq waardes van curves 1-5 van A zijn in B uitgezet tegen het aantal kopienummers in logaritmische schaal. Door het aantal kopienummers op logaritmische schaal uit te zetten, ontstaat er een rechte lijn in de grafiek; een lineair verband.

Door het lineaire verband tussen de twee factoren (cycli en kopienummers) kan er een lineaire vergelijking opgesteld worden, zoals de volgende formule:

$$
\text { Cq } \text { waarde }=a \times(\text { aantal kopienummers })+b
$$

Waarbij: $\quad a=$ De helling van de lineaire lijn

$\mathrm{b}=\mathrm{De} \mathrm{Cq}$ waarde waarbij het aantal kopienummers theoretisch nul is (zie

Figuur 1.2.4 B).

Door middel van deze formule kan aan de hand van de verkregen Cq waarde het aantal kopienummers berekend worden. 


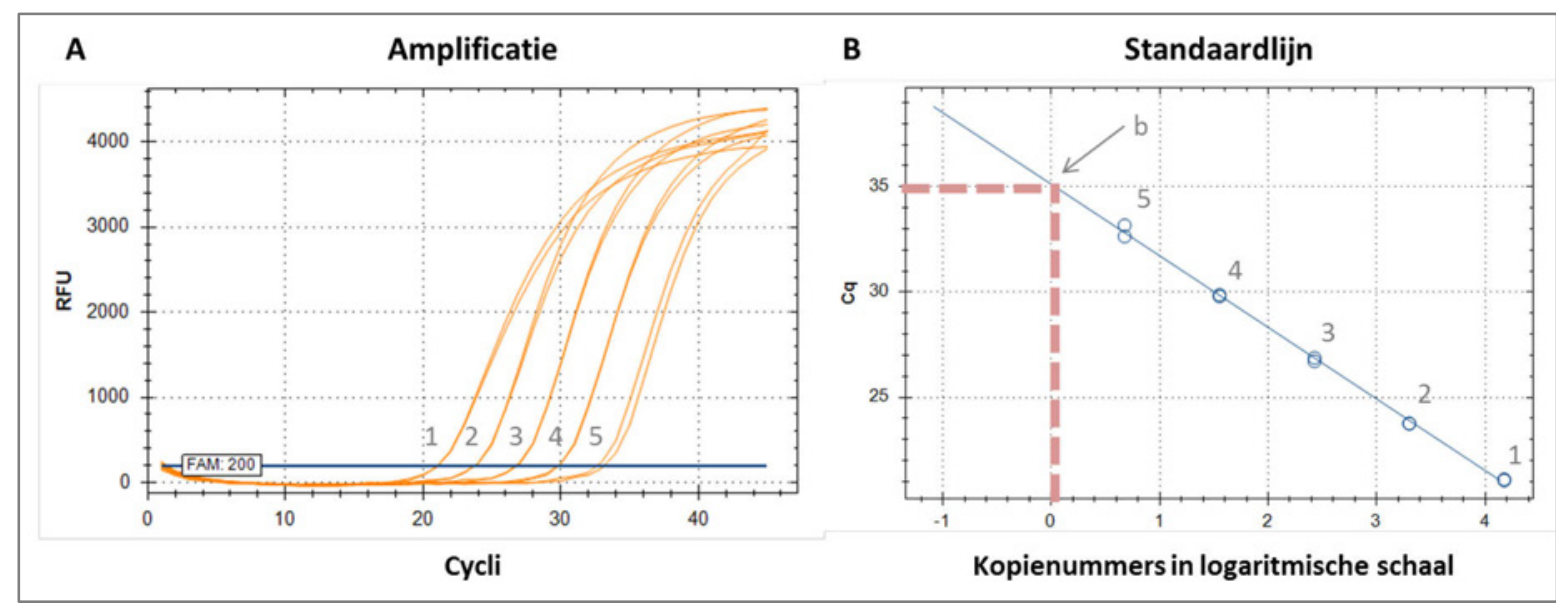

Figuur 1.2.4 Met behulp van qPCR-test is het mogelijk om een standaardlijn te maken op basis van kopienummers. In A zijn de amplificatie curves te zien van de verdunningsreeks; 5 verdunningen (nummers 1-5), 2 keer gemeten. De threshold is op 200 gezet. In B is de standaardlijn afgebeeld; kopienummers in logaritme zijn uitgezet tegen de Cq waardes. De Cq waarden van B nummers 1-5 komen overeen met de Cq waardes van de nummers 1-5 in A. In B is " $b$ " de Cq waarde waar het kopienummer theoretisch nul is, in dit geval is $b=35$. Efficiëntie $(E)$ is voor deze standaardlijn $97,0 \%$, de correlatie coëfficiënt $\left(R^{2}\right)$ is 0,998 .

Daarnaast geeft de thermal cycler nog twee waardes die een indicatie geven of je qPCR-test en je standaardlijn van goede kwaliteit zijn. Dit zijn de efficiëntie $(E)$ en de correlatie coëfficiënt $\left(R^{2}\right)$. In theorie zou in elke cyclus het DNA verdubbeld moeten worden, mits de reactie $100 \%$ efficiënt is. In praktijk is dit echter niet het geval en kan de efficiëntie verschillen per reactie. Bijvoorbeeld $95 \%$ voor het ene diersoort en $97 \%$ voor de andere diersoort. De standaardlijn in Figuur 1.2 .4 geeft een efficiëntie van $97,0 \%$. Meestal wordt een percentage tussen $90 \%-110 \%$ gezien als grenzen voor een goede efficiëntie. De correlatie coëfficiënt geeft aan of de experimentele data goed in de lineaire lijn past; lineariteit. De lineariteit geeft weer of de verdunningen voor de standaardlijn evenredig verdeeld zijn en dus als een rechte lijn weergegeven kan worden. Als de verdunningen perfect gemaakt en gedetecteerd zijn, zal $\mathrm{R}^{2}=1,000$ zijn. Door verschillende factoren is dit vaak niet het geval en daarom worden alle waardes voor $\mathrm{R}^{2}$ die groter zijn dan 0,98 geclassificeerd als goede lineariteit. In Figuur 1.2.4 zijn de verdunningen 1-5 in tweevoud getest. De repetities van elk afzonderlijke DNA monster komen niet helemaal overeen $\left(R^{2}=0,998\right)$ maar valt nog ruim binnen de gestelde grenswaarde van 0,98 .

\subsection{De essentie van semi-kwantitatieve bepaling}

Om het percentage te berekenen van een bepaalde diersoort in een vleesproduct, zijn er minstens twee verschillende qPCR-testen nodig. Een qPCR-test om het te bepalen diersoort aan te tonen en een qPCR-test die alle diersoorten aantoont. De test die alle diersoorten aantoont is bedoeld om de achtergrond te meten; het totale DNA dat afkomstig is van dieren. Hierdoor is het percentage van het bepaalde diersoort altijd ten opzichte van dierlijk materiaal. Als een product bijvoorbeeld $80 \%$ uit plantaardig materiaal bestaat en $20 \%$ uit dierlijk materiaal, kan de uitslag van de test alsnog aangeven dat het product uit $100 \%$ varken bestaat. Dit komt doordat de test alleen het dierlijke materiaal kan aantonen en het plantaardige materiaal niet. In plaats van een qPCR-test te gebruiken die alle diersoorten aantoont, kan er een qPCR-test gebruikt worden van een andere diersoort. Dan wordt de aanwezigheid van diersoort 1 aangeduid ten opzichte van diersoort 2 . 


\section{$1.4 \quad$ DNA: het startmateriaal}

In een qPCR-test zijn de primers en probe ontworpen op een stukje DNA van het genoom (de genetische informatie) van een bepaalde diersoort. Dit stukje genoom moet specifiek zijn voor het organisme dat gedetecteerd moet worden, bijvoorbeeld voor koe, paard, varken of kip. Het genoom waarop de primers en probe gebaseerd zijn, kan in verschillende locaties van de cel voorkomen in de diersoort. Er is namelijk nucleair DNA en mitochondrieel DNA aanwezig in de cel. Nucleair DNA wil zeggen dat het DNA in de celkern (nucleus) van de cel zit. Een celkern komt over het algemeen enkelvoudig voor in een cel.

Mitochondrieel DNA is het DNA van de mitochondriën. Mitochondriën zijn kleine organellen die meerdere keren voorkomen in de cel. Wetenschappelijk onderzoek heeft uitgewezen dat het aantal mitochondriën per cel erg kan verschillen en afhankelijk is van het type weefsel [11, 12]. Zo zit er bijvoorbeeld in 1 kilo vet-vlees veel minder mitochondriën dan in 1 kilo spier-vlees. Daarnaast verschilt het aantal mitochondriën per cel ook per diersoort [5].

\subsection{Singleplex en multiplex qPCR-testen}

Zoals beschreven in hoofdstuk 1.2, maakt een qPCR-test gebruik van de toename van fluorescentie. Deze fluorescentie is afkomstig van de probe. Als er in de test één probe aanwezig is, met daaraan één fluorofoor wordt dit een singleplex qPCR-test genoemd. Het is ook mogelijk om verschillende testen te combineren, als de probes verschillende fluoroforen hebben. Dit worden multiplex qPCRtesten genoemd. De primers en probes in een multiplex qPCR zijn gebaseerd op verschillende stukken in het DNA (Figuur 1.5.5). Bijvoorbeeld voor de toepassing om verschillende diersoorten aan te tonen, zijn de primers en probe met fluorofoor Geel gebaseerd op het DNA van varkens en primers en probe met fluorofoor Groen is gebaseerd op een stuk DNA dat terug komt in alle diersoorten zoals schematisch weergegeven in Figuur 1.5.1.

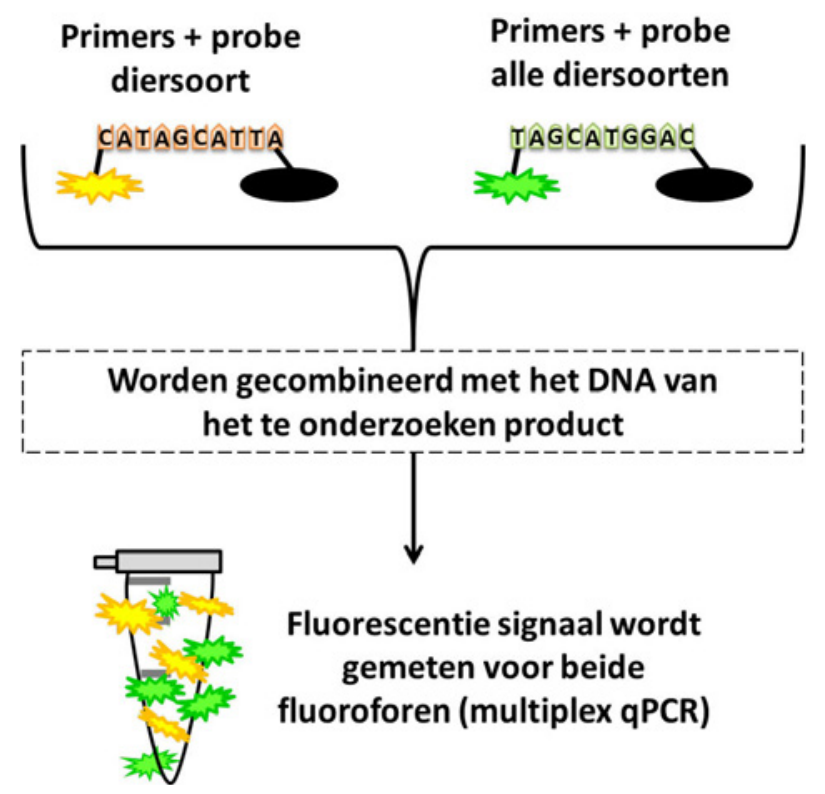

Figuur 1.5.1 Schematische weergave van een multiplex qPCR-test, met twee verschillende probes en daardoor ook twee verschillende fluoroforen om te detecteren. Multiplex qPCR kan ook met meer dan twee fluoroforen uitgevoerd worden. 


\section{Semi-kwantitatieve en kwalitatieve detectiemethoden}

Zoals in hoofdstuk 1 van dit rapport beschreven is, zijn er diverse detectie-kits beschikbaar die diersoorten in vleesmengsels kwantificeren met behulp van qPCR. Deze detectie-kits kunnen gebaseerd zijn op mitochondrieel DNA en nucleair DNA. De eigenschap van het DNA waarop de test is gebaseerd en de manier van data analyse worden meegenomen in de evaluatie van de verschillende methodes om vlees in vlees te kwantificeren. De evaluatie wordt gedaan op basis van commercieel verkrijgbare kits en een wetenschappelijk gepubliceerde methode [5] in vergelijk met de referentie methode van het EURL-AP. De EURL-AP referentiemethode is een semi-kwantitatieve detectiemethode waarvan het resultaat beschreven wordt als meer of minder dan $1 \%$ paardenvlees aangetoond. De commercieel verkrijgbare methode RapidFinder kan zowel kwalitatief als semi-kwantitatief gebruikt worden. Een overzicht van de verschillende beschikbare methoden is weergegeven in Tabel 2.1. Tevens zijn de verschillende eigenschappen weergegeven en een korte omschrijving van hoe de data interpretatie gedaan wordt.

In dit hoofdstuk worden de voor- en nadelen van een mitochondrieel of nucleaire test besproken, tevens van singleplex of multiplex qPCR-testen. Vervolgens wordt de manier van data interpretatie geëvalueerd en dit wordt beschreven in hoofdstuk 2.4.

Tabel 2.1 De eigenschappen van verschillende detectiemethoden en een korte omschrijving van de data interpretatie per methode.

\begin{tabular}{|c|c|c|c|c|}
\hline Methode & $\begin{array}{l}\text { Semi- } \\
\text { kwantitatief/ } \\
\text { kwalitatief }\end{array}$ & $\begin{array}{l}\text { Mitochondrieel/ } \\
\text { nucleair }\end{array}$ & $\begin{array}{l}\text { Singleplex/ } \\
\text { multiplex } \\
\text { qPCR }\end{array}$ & Data interpretatie op basis van... \\
\hline EURL-AP & Semi-kwantitatief & Mitochondrieel & Singleplex & $\begin{array}{l}\text { Cq drempelwaarde waarde op basis van } 1 \% \\
\text { paardenvlees DNA }\end{array}$ \\
\hline RapidFinder 1 & Semi-kwantitatief & Mitochondrieel & Singleplex & $\begin{array}{l}\text { Standaardlijn van bekend aantal DNA genoom } \\
\text { kopieën }\end{array}$ \\
\hline Nixon et al. & Semi-kwantitatief & Nucleair & Singleplex & Standaardlijn van $100 \%$ paardenvlees DNA \\
\hline Progenus & Semi-kwantitatief & Mitochondrieel & Multiplex & $\begin{array}{l}\text { Delta Cq, verschil in Cq waarden tussen twee } \\
\text { qPCR-testen }\end{array}$ \\
\hline Genesig & Semi-kwantitatief & Mitochondrieel & Multiplex & $\begin{array}{l}\text { Delta-delta Cq, verschil in Cq waarden tussen } \\
\text { monster en (meegeleverde) positieve controle, } \\
\text { en verschil in Cq waarden tussen twee qPCR- } \\
\text { testen }\end{array}$ \\
\hline RapidFinder 2 & Kwalitatief & Mitochondrieel & Multiplex & $\begin{array}{l}\text { Cq drempelwaarde waarde op basis van } 0,01 \% \\
\text { paarden DNA }\end{array}$ \\
\hline
\end{tabular}

\section{$2.1 \quad$ Matrix effect}

Zoals in hoofdstuk 1.1 al beschreven staat, is het correct bemonsteren en goed homogeniseren van het product van groot belang. Om het voorbeeld van de kroket er weer bij te halen; de kroket wordt deze keer helemaal gemalen, samen met andere kroketten. Vervolgens wordt er DNA geëxtraheerd van dit mengsel en een qPCR-test wordt uitgevoerd. Doordat een kroket niet alleen uit puur vlees bestaat maar ook uit bijvoorbeeld paneermeel, zout en andere specerijen, kunnen die andere ingrediënten invloed hebben op de efficiëntie van de qPCR-test. Zelfs puur vlees kan al invloed hebben op de efficiëntie van de qPCR-test, door bijvoorbeeld de aanwezigheid van (natuurlijk) vet. Dit wordt ook wel het matrix effect genoemd en kan zorgen voor remming in de qPCR-test en daardoor invloed hebben op de semi-kwantitatieve en kwalitatieve bepaling. Tevens kan het voorkomen bij bewerkte vlees producten, zoals een frikandel, dat het ene diersoort meer verhit of gemalen is dan het andere diersoort. Door dit proces kan het DNA beschadigd zijn of zelfs afgebroken worden en dit kan invloed 
hebben op de amplificatie van het DNA $[1,8]$. Dit zijn ook factoren die invloed kunnen hebben op de semi-kwantitatieve en kwalitatieve bepaling, ongeacht of de qPCR-test gebaseerd is mitochondrieel of nucleair DNA. Het type DNA waarop de methode gebaseerd is, kan ook voor een matrix effect zorgen. Dit wordt besproken in hoofdstuk 2.2.

\subsection{Voor- en nadelen van mitochondriële en nucleaire qPCR-testen}

De aanwezigheid van een bepaalde diersoort in een product moet uitgedrukt zijn in procent en vermeld worden op het etiket $[2,3]$. Dit percentage is gebaseerd op de verhouding tussen gewicht diersoort/gewicht totale product $(\mathrm{w} / \mathrm{w})$. Zoals beschreven staat in hoofdstuk 1.4, verschilt het aantal mitochondriële kopieën niet alleen per weefsel maar ook per diersoort. Daardoor wordt het bepalen van het percentage erg lastig op basis van een mitochondriële qPCR-test; dit is enigszins alleen mogelijk als de weefselsamenstelling van alle ingrediënten in het product bekend is en gelijkwaardig aan elkaar is $[5,11,12]$. Dit is vaak niet het geval waardoor kwantificering wordt bemoeilijkt. In Figuur 2.2.1 is een schematisch overzicht weergegeven over kwalitatieve en semi-kwantitatieve bepalingen in diersoorten. Hier worden voor beide bepalingen de voor- en nadelen benoemd voor qPCR-testen die gebaseerd zijn op mitochondrieel of nucleair DNA.

\begin{tabular}{|c|c|}
\hline $\begin{array}{l}\text { Mogelijkheden van } \\
\text { kwalitatieve bepalingen } \\
\text { in diersoorten }\end{array}$ & $\begin{array}{l}\text { Mitochondrieel DNA } \\
\text { Voordelen: } \\
\text { - Meeste cellen bevatten meerdere } \\
\quad \text { mitochondriële DNA kopieën. } \\
\text { - } \quad \text { Lage detectie grens (LOD). } \\
\text { Nadelen: } \\
\text { - Gevoelig voor contaminatie. }\end{array}$ \\
\hline \multirow{3}{*}{$\begin{array}{l}\text { Mogelijkheden van semi- } \\
\text { kwantitatieve bepalingen } \\
\text { in diersoorten }\end{array}$} & $\begin{array}{l}\text { Nucleair DNA } \\
\text { Voordelen: } \\
\text { - Gemakkelijk om diersoort-specifieke } \\
\text { primers te ontwerpen en tonen geen } \\
\text { andere diersoorten aan (cross- } \\
\text { reactiviteit). } \\
\text { Nadelen: } \\
\text { - Hoge detectie grens (LOD). }\end{array}$ \\
\hline & $\begin{array}{l}\text { Mitochondrieel DNA } \\
\text { Voordelen: } \\
\text { - Lage detectie grens (LOD). } \\
\text { Nadelen: } \\
\text { - Grote verschillen in hoeveelheid } \\
\text { mitochondriën tussen verschillende } \\
\text { weefsels en diersoorten. } \\
\text { - Niet mogelijk om een zinvolle } \\
\text { kwantificatie te doen, zowel op DNA } \\
\text { als gewicht basis (w/w). }\end{array}$ \\
\hline & $\begin{array}{l}\text { Nucleair DNA } \\
\text { Voordelen: } \\
\text { - Kwantificatie is mogelijk doordat het } \\
\text { genoom in gelijke hoeveelheden } \\
\text { aanwezig is; gebaseerd op } \\
\text { gelijkwaardig DNA. } \\
\text { Nadelen: } \\
\text { - Hoeft geen afspiegeling te zijn van } \\
\text { het gewicht (w/w) } \\
\text { - Hoge detectie grens (LOD). }\end{array}$ \\
\hline
\end{tabular}

Figuur 2.2.1 Een schematisch overzicht over de mogelijkheden van kwalitatieve en semikwantitatieve bepalingen in diersoorten (aangepast vanuit Ballin et al. 2009 [1]). 
Het voordeel van mitochondriële qPCR-testen is dat het erg gevoelige testen zijn. Omdat er zoveel mitochondrieel DNA aanwezig is, is het relatief gemakkelijk om een bepaalde diersoort aan te tonen, ook in verhit materiaal. Mitochondriële qPCR-testen kunnen ook gebruikt worden voor kwantitatieve bepalingen, maar dit is enigszins mogelijk als de samenstelling van het product gelijkwaardig is aan elkaar. Dat wil zeggen dat het vlees dat gebruikt is, afkomstig is van hetzelfde weefsel van de diersoorten. Maar om een goede weergave van de werkelijkheid te geven blijft lastig op basis van mitochondrieel DNA, omdat de hoeveelheid mitochondriën en daarmee het te amplificeren DNA, is ook verschillend per diersoort.

Het grootste voordeel van een nucleaire qPCR-test is dat deze test in theorie wel te kwantificeren is. Dit komt doordat aan de hand van het genoomgewicht te berekenen is hoeveel nucleair DNA er aanwezig is in een DNA monster. Echter, het genoomgewicht is voor elke diersoort verschillend. Daardoor is kwantificering van een mengsel met twee bekende diersoorten wel uit te voeren, maar een kwantificering met meerdere en/of onbekende diersoorten op basis van genoomgewicht niet nauwkeurig meer. Daarom is kwantificering op basis van nucleaire qPCR-testen alleen mogelijk als er gebruik gemaakt wordt van gelijkwaardige diersoorten. Daarnaast hoeft kwantificering op DNA basis geen afspiegeling te zijn van het daadwerkelijke percentage gebaseerd op het gewicht van het vlees. Dit komt doordat niet elke cel en elk weefsel even zwaar is, maar er kan wel evenveel nucleair DNA uit geëxtraheerd worden.

Nucleaire qPCR-testen hebben een hogere detectie grens (Limit Of Detection, LOD) dan een mitochondriële qPCR-test. Dat wil zeggen dat een mitochondriële qPCR-test gevoeliger is dan een nucleaire test doordat mitochondrieel DNA in grotere hoeveelheden aanwezig is.

\subsection{Voor- en nadelen van singleplex en multiplex qPCR- testen}

Het voordeel van multiplex qPCR-test ten opzichte van een singleplex qPCR-test is dat meerdere diersoorten in hetzelfde product (DNA monster) getest kunnen worden. Daarnaast wordt bijvoorbeeld de variatie in het toevoegen van DNA geminimaliseerd; als er twee losse testen gedaan worden kan het zijn dat er in de ene test meer DNA toegevoegd wordt dan in de andere test.

Het nadeel van een multiplex qPCR-test is dat de het ene fluorescente signaal het andere signaal kan verstoren. Tevens kunnen de chemicaliën, zoals de losse nucleotiden, in de reactie opraken. Dit gaat sneller in een multiplex qPCR-test omdat er twee reacties tegelijk uitgevoerd moeten worden. Deze factoren kunnen invloed hebben op het kwantificeren van een diersoort doordat de efficiëntie van de qPCR-test minder wordt [8].

\subsection{Verschillende detectiemethoden; de data-interpretatie}

Een ander belangrijk deel van het kwantificeringsprocedure is de manier van data verwerking en de interpretatie ervan. In dit hoofdstuk wordt er per detectiemethode de data-interpretatie kort beschreven en geëvalueerd. Een overzicht van de verschillende methoden is te vinden in Tabel 2.1.

\subsubsection{EURL-AP (semi-kwantitatief)}

Naar aanleiding van het paardenvlees incident in 2013, is er een detectiemethode opgezet om $1 \%$ of meer paardenvlees te kunnen aantonen in vleesproducten. Deze $1 \%$ drempelwaarde is bepaald om het verschil weer te kunnen geven tussen onvoorziene verontreiniging (contaminatie) of opzettelijk toevoegen van paardenvlees (fraude) [13].

De referentiemethode is gebaseerd op mitochondrieel DNA van paard en er wordt gebruik gemaakt van een $1 \%$ pardenvleesmengsel als drempelwaarde. Dit paardenvlees mengsel is een gestandaardiseerde controlemonster gemaakt uit vers vlees en deze wordt aangeleverd door het EURL-AP.

Deze drempelwaarde is alleen geldig voor vleesmengsels gemaakt uit rauw vlees. Als andere meer gecompliceerde mengsels worden getest, zal de analyse zo goed mogelijk gericht moeten zijn op het 
vlees in het product. Bij gebrek aan een beter alternatief, zal de $1 \%$ drempelwaarde ook voor deze mengsels toegepast worden maar zal deze drempelwaarde enigszins minder streng zijn [14].

De drempelwaarde wordt bepaald door een aantal herhalingen van de qPCR-test te verrichten met het $1 \%$ paardenvleesmengsel als monster. Van de Cq waarde die hieruit bepaald wordt, wordt een halve $\mathrm{Cq}$ afgetrokken. Het voordeel van deze methode is dat er alleen gekeken wordt naar de aanwezigheid van paarden DNA in een vleesmengsel. En dus niet ten opzichte van de achtergrond; andere diersoorten. Het matrix effect blijft wel bestaan; remming in de qPCR-test kan altijd voorkomen.

\subsubsection{RapidFinder1 (semi-kwantitatief)}

Voor deze methode wordt er gebruik gemaakt van een standaardlijn die gebaseerd is op een positieve controle die meegeleverd is. Deze positieve controle bevat synthetisch DNA waarvan bekend is hoeveel DNA kopieën er aanwezig zijn. Tevens is het een singleplex, mitochondriële qPCR-test. Door gebruik te maken van singleplex is het eventuele nadeel van multiplex niet aanwezig; elke reactie kan optimaal gebruik maken van de chemicaliën die aanwezig zijn.

Door de standaardlijn kan er per monster uitgerekend worden hoeveel DNA kopieën er aanwezig zijn, voor zowel het te bepalen diersoort als voor alle diersoorten. Met behulp van de twee qPCR-testen kan de ratio berekend worden van de diersoort ten opzichte van alle diersoorten die aanwezig zijn in het monster. Vermenigvuldigd met $100 \%$ is het eindelijke resultaat in procent voor het te bepalen diersoort ten opzichte van alle diersoorten.

Doordat er een standaardlijn gemaakt wordt aan de hand van bekende DNA kopieën, zal de schatting van de DNA kopieën per monster meer accuraat zijn ten opzichte van een standaardlijn die gemaakt is aan de hand van DNA afkomstig van vlees. DNA afkomstig van vlees kan niet bepaald worden hoeveel mitochondriën er aanwezig zijn en dus is het niet mogelijk om te bepalen hoeveel DNA kopieën er aanwezig zijn en dit te reflecteren op de monsters.

Ook al kunnen de kopieën nu wel goed gedefinieerd worden, is het geen afspiegeling van de werkelijke situatie. Er wordt namelijk geen rekening gehouden met het matrix effect. De efficiëntie van de qPCR-test kan in de standaardlijn optimaal zijn, hier zijn geen remmende factoren die wel aanwezig kunnen zijn in vlees. Zoals in hoofdstuk 2.1 genoemd is, zijn dit bijvoorbeeld vetten en zouten. Daarnaast kan het DNA ook meer afgebroken zijn in DNA afkomstig uit vlees. Door deze remmende factoren kan de efficiëntie van de qPCR-test verschillen in de standaardlijn met de efficiëntie van de qPCR-test op DNA afkomstig uit vlees. Om hier een indicatie van te hebben, zou een extra verdunningsreeks gemaakt kunnen worden van het DNA afkomstig uit vlees [8]. Door de hierboven genoemde factoren zal kwantificeren van een diersoort in een vleesmengsel volgens deze methode niet accuraat zijn.

\subsubsection{Nixon et al. (semi-kwantitatief)}

Ook deze methode is gebaseerd op het maken van een standaardlijn, waaruit het aantal DNA kopieën van de monsters berekend kan worden. De qPCR test is gebaseerd op nucleair DNA en wordt in enkelvoudige reacties uitgevoerd. Het voordeel van deze methode ten opzichte van een mitochondriële test is, dat het aantal nucleaire DNA kopieën gelijk is in elke cel, ongeacht van wat voor soort weefsel het vlees afkomstig is. Dit maakt het kwantificeren in de eerste instantie nauwkeuriger.

De standaardlijn is niet gemaakt uit een meegeleverde positieve controle zoals bij de RapidFinder methode, maar is gebaseerd op DNA uit bijvoorbeeld puur paardenvlees als het percentage paard bepaald moet worden. Deze standaardlijn wordt getest met twee verschillende qPCR testen; een paarden-qPCR en een qPCR test die zoogdieren en gevogelte detecteert.

In de methode staat beschreven dat het aantal genoom kopieën van beide standaardlijnen gebaseerd op het genoomgewicht van één diersoort (paard). De standaardlijnen zijn daardoor gedefinieerd als gelijkwaardig aantal kopieën. Dit is echter niet geheel correct als er mengsels worden onderzocht met deze methode; het gewicht van het genoom verschilt per diersoort [1]. Wanneer deze methode toegepast wordt, is het alleen mogelijk om een correcte schatting te geven van een percentage als de andere diersoorten in het product vergelijkbare genoomgewichten hebben. Deze methode zal wel goed werken voor een mengsel van twee bekende diersoorten, mits de standaardlijnen gedefinieerd worden naar de diersoort waarop de qPCR-test gebaseerd is. 
De standaardlijn gebaseerd op DNA afkomstig van vlees komt meer in de buurt van het materiaal (monsters) die getest moeten worden namelijk vlees. Dit heeft als voordeel dat de factoren die in het vlees zitten en die invloed hebben op de qPCR-test (matrixeffect), ook meegenomen worden in de standaardlijn. Dit kan ook een nadeel zijn voor de standaardlijn; er kan al remming optreden in de verdunningsreeks waardoor de standaardlijn niet voldoet aan de eisen die gesteld worden zoals de efficiëntie van de qPCR-test en $\mathrm{R}^{2}$.

\subsubsection{Progenus (semi-kwantitatief)}

De qPCR test is gebaseerd op mitochondrieel DNA en wordt uitgevoerd als een multiplex reactie. In tegenstelling tot de twee methoden beschreven in hoofdstuk 2.4.2 en 2.4.3., is deze methode niet gebaseerd op een standaardlijn, maar op het verschil in $\mathrm{Cq}$ waarden. Deze methode gaat er van uit dat de qPCR testen in de multiplex reactie beide gelijke efficiëntie heeft. Dat wil zeggen dat elke cyclus exact een verdubbeling van het aantal DNA kopieën. Dit is vaak niet het geval en er zou dus rekening gehouden moeten worden met de efficiëntie van de GPCR testen in deze methode, met betrekking tot kwantificering [15]. De efficiëntie van de qPCR testen moeten nagenoeg gelijk zijn aan elkaar, omdat grote verschillen in efficiëntie leiden tot een minder nauwkeurige kwantificering.

\subsubsection{Genesig (semi-kwantitatief)}

De analyse die bij deze methode gebruikt wordt, komt in principe overeen met de methode beschreven onder hoofdstuk 2.4.4. De Genesig methode is een multiplex qPCR-test, gebaseerd op mitochondrieel DNA en maakt geen gebruik van standaardlijnen maar van een verschil in Cq waarden. Het verschil tussen de analyse methode van Progenus en de methode van Genesig, is dat er in de methode van Genesig een positieve controle wordt meegenomen. Deze positieve controle is onderdeel van de detectie-kit. De functie van deze controle is om de qPCR-testen te normaliseren [10]. Dat wil zeggen dat de $\mathrm{Cq}$ waarden van de monsters gelijk worden getrokken met een positieve referentie controle. De normalisatie wordt gedaan door het verschil in Cq waarde te berekenen tussen de positieve controle en de te bepalen diersoort en tussen de positieve controle en alle diersoorten. Deze manier van data interpretatie wordt ook wel de delta-delta-Cq methode genoemd [16]. Ook in deze analyse wordt er geen rekening gehouden met het verschil in efficiëntie van de qPCR-test [17] en kan ook voor deze methode de kwantificering niet accuraat zijn.

\subsubsection{RapidFinder2 (kwalitatief)}

De methode beschreven onder hoofdstuk 2.4.2 kan naast semi-kwantitatief, ook kwalitatief gebruikt worden. Om de methode voor deze toepassing te gebruiken, is er een positieve controle meegeleverd met de kit; 0,1\% paarden DNA. De drempelwaarde waarde wordt berekend door de Cq van de 0,1\% paarden DNA nog 3.32 cycli erbij op te tellen (dit is in theorie een factor 10 minder). Als de qPCR-test efficiënt gebeurd, wil dit zeggen dat de Cq waarde van de drempelwaarde met een factor 10 verschilt en zal de drempelwaarde waarde liggen rond de 0,01\% paarden DNA. Alle monsters die een $\mathrm{Cq}$ waarde geven voor deze $\mathrm{Cq}$ drempelwaarde, worden geclassificeerd als aangetoond. Alle monsters die een latere $\mathrm{Cq}$ waarde geven dan deze drempelwaarde, worden gezien als niet aangetoond.

Het verschil, en ook het voordeel, van deze methode ten opzichte van de EURL-AP methode is dat er gebruik gemaakt wordt van een interne positieve controle (IPC). Hierdoor kan per monster een indicatie gegeven worden of er door de matrix remming veroorzaakt wordt. Hoewel de Cq waarden van de IPC's ook kunnen verschillen als er veel paarden DNA aanwezig is in het monster; dan zijn alle chemicaliën in de reactie al opgebruikt door de qPCR-test van paard en zijn er niet voldoende chemicaliën over om de qPCR-test van de IPC volledig en efficiënt uit te voeren. Dit wordt ook aangegeven in het protocol van de methode. 


\subsection{Conclusie}

Door alle verschillende factoren waar rekening mee gehouden moet worden is er nog geen methode gevonden die het percentage van diersoorten in vleesproducten op een nauwkeurige wijze kan bepalen. De verschillende factoren waar rekening mee gehouden moet worden zijn:

- De eigenschap van het DNA: mitochondrieel of nucleair DNA

- Het matrix effect dat veroorzaakt wordt door de oorsprong van het vlees: diersoort, weefsel

- Het matrix effect dat voor remming zorgt in de reactie: extra ingrediënten zoals zout etc.

- De verschillen in efficiëntie van de qPCR-test(en)

Naast de factoren waar rekening mee gehouden moet worden, zijn er ook verschillende manieren van data interpretatie en analyse. Hierdoor kan het voorkomen dat het resultaat (het percentage) voor hetzelfde monster verschilt per methode. Door deze factoren is er een verhoogt risico op verschillende uitslagen met name rond de drempelwaarde.

Door alle semi-kwantitatieve methoden kwalitatief te interpreteren, kan er een uitslag gegeven worden of een diersoort aangetoond of niet aangetoond is. Maar het percentage van de aanwezige diersoort is niet nauwkeurig te bepalen, omdat er te veel factoren zijn die het resultaat beïnvloeden. 


\section{Introductie op de praktische vergelijking van een aantal methoden voor de detectie van paardenvlees}

In richtlijn 2000/13/EG [2] en in aanbeveling 2013/99/EU [3] staat dat de consument niet misleid mag worden ten aanzien van de kenmerken van het levensmiddel. Als er dierlijke producten verwerkt zijn in een levensmiddel, moet er vermeld worden welk diersoort het is en in welke hoeveelheid, uitgedrukt in procenten, de diersoort aanwezig is. In aanbeveling 2014/180/EU [4] staat beschreven dat voor het testen van de aanwezigheid van paardenvlees, een eerste screeningsmethode gebruikt moet worden die minimaal 0,5\% paardenvlees aan kan tonen. Mochten de resultaten voor deze screening positief zijn, dan moeten de resultaten bevestigd worden met een qPCR test gebaseerd op mitochondrieel DNA. Het European Union Reference Laboratory for Animal Proteins in feedingstuffs (EURL-AP) heeft een test ontwikkeld die voldoet aan deze eisen. Deze referentiemethode mag uitsluitend gebruikt worden door laboratoria die daarvoor bevoegd zijn. Er wordt een detectiegrens (drempelwaarde) gehanteerd die gebaseerd is op een mengsel bestaande uit $1 \%$ paardenvlees in rundvlees. Dit mengsel is gemengd op gewichtsbasis, gehomogeniseerd en vervolgens verdeeld over de handhavingslaboratoria. De $1 \%$ paardenvlees drempelwaarde wordt uitgedrukt in Cq waarde. Alle monsters die een Cq waarde geven die lager is dan deze $1 \%$ paardenvlees drempelwaarde, zullen worden gerapporteerd als monsters waarbij de massafractie van $1 \%$ paardenvlees overschreden is [14].

In dit deel van het rapport worden commercieel beschikbare detectiekits en -methoden, die gebruikt kunnen worden om te toetsen of aan de regelgeving wordt voldaan, praktisch geëvalueerd en vergeleken met de EURL-AP referentiemethode. Alle geteste methoden worden samengevat in Tabel 3.1. Per methode wordt er aangegeven of het een semi-kwantitatieve of kwalitatieve methode is, of de methode gebaseerd is op mitochondrieel of nucleair DNA en er wordt een korte beschrijving gegeven hoe de datainterpretatie gedaan wordt, dit laatste conform de informatie die bij de methode wordt meegeleverd.

Methode 1 is de EURL-AP referentiemethode [14, 18], methode 2, 4, 5 en 6 zijn commercieel verkrijgbaar en methode 3 is een wetenschappelijk gepubliceerde methode door Nixon et al. [5].

Tabel 3.1 Overzicht van de verschillende geteste detectiemethoden. Per methode is aangegeven of dit een semi-kwantitatieve of kwalitatieve test is, of de methode gebaseerd is op mitochondrieel of op nucleair DNA en in het kort hoe de data-interpretatie gedaan wordt bij de betreffende methode.

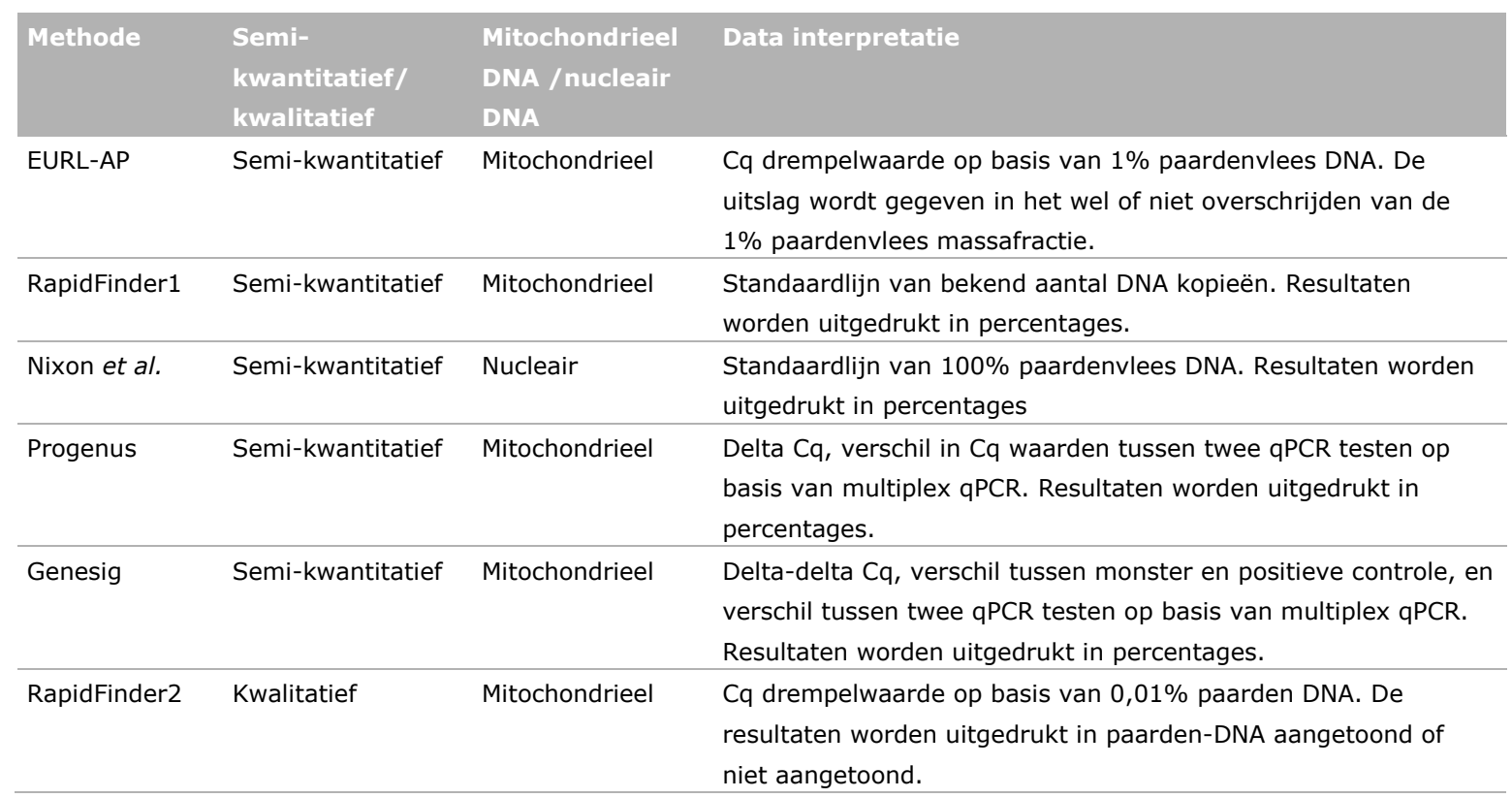




\section{$4 \quad$ Materiaal en methoden}

\subsection{Vleesmengsels}

Elke methode is getest op dezelfde serie monsters (Tabel 4.1.1) volgens het voorgeschreven protocol van de fabrikant. Allereerst is er een verdunningsreeks gemaakt van paardenvlees in rundvlees. De volgende percentages zijn daardoor verkregen: $100 \%, 10 \%, 1 \%, 0,1 \%$ en $0 \%$ paardenvlees in rundvlees. Verder is er een $1 \%$ paardenvlees mengsel gemaakt in een achtergrond van een snackproduct. Deze $1 \%$ paardenvlees in snack wordt ook getest, net als het snackproduct zonder bijmenging van paardenvlees ( $0 \%$ paardenvlees in snack). Het snackproduct bevat volgens het etiket geen rundvlees, maar wel kip en varken. Daarnaast is het mengsel van $1 \%$ paardenvlees in rundvlees getest, dat gebruikt wordt bij de EURL-AP referentiemethode (methode 1 ).

Tabel 4.1.1 De eigenschappen van de verschillende monsters waarvan DNA geëxtraheerd is. Van elk monster zijn er twee DNA-extracties gedaan.

\begin{tabular}{|c|c|}
\hline Monster & Omschrijving \\
\hline $100 \%$ paardenvlees $/ 0 \%$ rundvlees & \multirow{3}{*}{$\begin{array}{l}\text { Vleesverdunningsreeks; paardenvlees vermengd in een rundvlees achtergrond } \\
\text { op gewichtsbasis. }\end{array}$} \\
\hline $10 \%$ paardenvlees $/ 90 \%$ rundvlees & \\
\hline $0.1 \%$ paardenvlees $/ 99.9 \%$ rundvle & \\
\hline $1 \%$ paardenvlees/99\% snack & \multirow{2}{*}{$\begin{array}{l}\text { Andere } 1 \% \text { paardenvleesmengsels; hetzelfde paardenvlees als in de } \\
\text { vleesverdunningsreeks, maar in een andere achtergrond (snack). En de } \\
\text { officiële EURL-AP } 1 \% \text { paardenvlees in rundvlees. }\end{array}$} \\
\hline officiële EURL-AP standaard & \\
\hline $0 \%$ paardenvlees/100\% rundvlees & \multirow{2}{*}{$\begin{array}{l}\text { Negatieve controles voor de vleesverdunningsreeks en voor de } 1 \% \\
\text { paardenvlees in een snack achtergrond. }\end{array}$} \\
\hline $0 \%$ paardenvlees $/ 100 \%$ snack & \\
\hline
\end{tabular}

\subsection{DNA isolatie}

Om de detectiemethoden met elkaar te kunnen vergelijken wordt er gebruik gemaakt van hetzelfde DNA dat op identieke manier verkregen is (dezelfde DNA-extractie). Het DNA-extractie protocol dat gebruikt is, wordt aanbevolen door de EURL-AP referentiemethode [14]. Het protocol is gebaseerd op de ISO-standaard ISO-21571:2005 Appendix A.3.1.

$\mathrm{Bij}$ elke methode is er een extractie-controle meegenomen en een watercontrole. De extractie controle is water dat hetzelfde DNA-extractie protocol doorlopen heeft als de monsters. Dit wordt gedaan om het DNA-extractie proces te controleren of er geen onvoorziene verontreiniging optreedt tijdens het DNA extraheren. De water controle is een geen-DNA-controle; deze controle wordt meegenomen in de qPCR-testen om te zien of de reacties/chemicaliën van de qPCR verontreiniging-vrij zijn.

\subsection{Detectiemethoden}

In dit deel van het rapport worden de vijf detectiemethoden die getest zijn, vergeleken met de EURL-AP referentiemethode. In het volgende sub-hoofdstuk wordt de werking van de EURL-AP referentiemethode beschreven, gevolgd door de verschillende detectiemethoden die onderwerp van het onderzoek zijn. De set monsters beschreven onder hoofdstuk 4.1 is getest met elke detectiemethode en vervolgens is er per monster berekend hoeveel procent paardenvlees het bevat. Als dit percentage groter dan $1 \%$ is, wordt het uiteindelijke resultaat voor dat monster dat er meer dan $1 \%$ paardenvlees aanwezig is. Deze uitslag wordt vergeleken met het resultaat van de EURL-AP referentiemethode om de verschillen en overeenkomsten tussen de methoden in kaart te brengen. 


\subsubsection{EURL-AP referentiemethode (semi-kwantitatief)}

De referentiemethode van het EURL-AP is gebaseerd op mitochondrieel DNA van paard. De eerste stap in deze methode is om te bepalen bij welke verdunningsfactor er geen remming meer optreedt in de qPCR test. Dit wordt gedaan door verdunningsreeksen te maken van 5 extracten van $1 \%$ paardenvlees in rundvlees DNA en vervolgens de delta Cq methode toe te passen om de praktische verdunningsfactor te berekenen;

$$
\text { Praktische verdunningsfactor }=2 \text { (Cq hoge verdunning }- \text { Cq lage verdunning) }
$$

De praktische verdunningsfactor moet overeenkomen met de verdunningsfactor waarmee theoretisch verdund is. Als dit niet het geval is, is er remming in de qPCR-test tussen de twee verdunningen en moet er verder verdund worden. Zo wordt de ideale verdunningsfactor bepaald.

Zodra de ideale verdunningsfactor bepaald is, wordt de drempelwaarde bepaald, uitgedrukt in $\mathrm{Cq}$ waarde. Dit wordt gedaan door de gemiddelde Cq waarde te nemen van een aantal herhalingen van $1 \%$ paardenvlees in rundvlees DNA. Deze drempelwaarde mag een standaardafwijking hebben die niet meer dan 0,25 cyclus is. Vervolgens wordt de drempelwaarde berekend aan de hand van de volgende formule:

$$
\text { Cq drempelwaarde }(1 \%)=\text { Gemiddelde } \mathrm{Cq}-0,5 \text { cyclus }
$$

Er wordt per monster bepaald of de drempelwaarde overschreden is. Om te beginnen wordt elk DNAextract in duplo getest voor de qPCR-test. De gemiddelde Cq waarde per DNA-extract wordt berekend. Vervolgens worden de verschillende DNA-extracten van hetzelfde monster apart geëvalueerd. Dit wil zeggen dat als de Cq waardes van beide DNA-extracten groter zijn dan de drempelwaarde, er minder dan $1 \%$ paarden-DNA aanwezig is. Als beide DNA extracten een Cq waarde geven kleiner dan de drempelwaarde, dan is er meer dan $1 \%$ paarden-DNA aanwezig in het monster.

Het uiteindelijke resultaat van de referentiemethode is of er meer of minder dan $1 \%$ paardenvlees aanwezig is in het (vlees)monster.

\subsubsection{RapidFinder1 (semi-kwantitatief)}

De methode RapidFinder 1 (imegen, LifeTechnologies ${ }^{T M}$ ) is gebaseerd op mitochondrieel DNA, voor zowel specifiek paarden DNA als voor alle soorten vlees ("total animal"). Verder zijn de qPCR-testen singleplex, dat wil zeggen dat de monsters met twee verschillende reacties getest worden. Als extra controle voor de monsters zit er in de paarden-qPCR-test een interne positieve controle (IPC); deze controle geeft een indicatie of de monsters zorgen voor remming in de qPCR-test.

Om het percentage paarden DNA te kunnen bepalen in de monsters, wordt er in deze methode gebruik gemaakt van een standaardlijn. Deze standaardlijn is gebaseerd op een meegeleverd monster, waarvan het exacte aantal DNA kopieën bekend is en waarmee een verdunningsreeks gemaakt kan worden die gedefinieerd wordt op het aantal kopieën. Deze standaardlijn wordt uitgezet voor zowel de alle-diersoorten-qPCR-test als voor de paard-specifieke-qPCR-test. Hiermee kan, als voldaan wordt aan de kwaliteitscriteria, het aantal DNA kopieën per monster vastgesteld worden voor beide qPCRtesten. De methode moet voldoen aan de criteria in Tabel 4.3.2.1.

Tabel 4.3.2.1 Criteria waaraan de qPCR-test moet voldoen in de RapidFinder1 detectiemethode.

\begin{tabular}{lll} 
Type monster & Paard-qPCR & \multicolumn{1}{c}{ Vlees-qPCR } \\
Extractie controle of geen-DNA-controle & Niet gedetecteerd & Niet gedetecteerd \\
\cline { 2 - 3 } (water) & IPC: gedetecteerd & IPC: niet gedetecteerd \\
\hline Verdunningsreeks & Alle vijf de verdunningen moeten gedetecteerd zijn. \\
& \\
& De standaardlijn moet voldoen aan de volgende criteria: \\
& - De efficiëntie moet tussen de $90-110 \%$ zijn \\
& - (helling moet tussen -3.6 en -3.1 zijn) \\
& - - De correlatie coëfficiënt $\left(R^{2}\right)$ moet groter dan 0.98 zijn.
\end{tabular}


Om te kunnen kwantificeren moeten de Cq waarden van het monster binnen de standaardlijn vallen. Is dit het geval, dan kan er een schatting gedaan worden voor het percentage paarden DNA dat aanwezig is in het monster. Dit wordt gedaan door middel van de volgende formule:

$$
\text { Percentage paard }=\frac{\text { Aantal kopieën paard }}{\text { Aantal kopieën alle diersoorten }} \times 100 \%
$$

Elke DNA-extractie is in duplo getest in de qPCR-test en per qPCR-test is het percentage paard berekend. Vervolgens is het gemiddelde percentage paard per monster uitgerekend. Dit betekent dat er per monster het gemiddelde is genomen van vier percentages.

\subsubsection{Nixon et al. (semi-kwantitatief)}

Deze wetenschappelijk gepubliceerde methode [5] is gebaseerd op nucleair DNA. De methode beschrijft zowel een qPCR-test om paarden-DNA aan te tonen als een qPCR-test om zoogdier/gevogelte DNA aan te tonen. Deze twee testen worden apart uitgevoerd op de monsters, het zijn dus singleplex qPCR-testen.

In de methode wordt gebruik gemaakt van een standaardlijn die gebaseerd is op DNA uit $100 \%$ paardenvlees. De verschillende verdunningen van de standaardlijnen zijn gedefinieerd aan de hand van het genoomgewicht van paarden-DNA, voor zowel de paarden qPCR-test als voor de zoogdier/gevogelte qPCR-test.

De standaardlijnen moeten voldoen aan de volgende criteria:

- De efficiëntie van de qPCR-test moet tussen de 90-110\% zijn

- De correlatie coëfficiënt $\left(R^{2}\right)$ moet groter dan 0.98 zijn.

Het percentage paarden DNA in de monsters wordt als volgt berekend:

$$
\text { Percentage paard }=\frac{\text { Aantal kopieën paard }}{\text { Aantal kopieën zoogdier/gevogelte }} \times 100 \%
$$

Elke DNA-extractie is in drievoud getest voor elke qPCR-test. Vervolgens is het gemiddeld aantal DNA kopieën berekend per DNA-extractie per qPCR-test. Met dit gemiddeld aantal DNA kopieën is het percentage paard berekend per DNA isolatie. Om het percentage per monster te berekenen, is het gemiddelde percentage berekend van de twee DNA isolaties.

\subsubsection{Progenus (semi-kwantitatief)}

In de methode van Progenus (Progenus s.a.) wordt gebruik gemaakt van mitochondriële qPCR-testen die gebaseerd zijn op multiplex qPCR. Dat wil zeggen dat zowel de paarden qPCR-test als de vertebraten (gewervelden) qPCR-test tegelijk op het monster uitgevoerd worden, in 1 reactie. Het percentage wordt niet berekend aan de hand van een standaardlijn, maar door middel van het verschil in Cq waarden tussen de twee verschillende qPCR-testen. De grenswaarde van beide testen moet gelijk gezet worden en daarna kan bepaald worden of de test geldig is. De test is geldig als voldaan wordt aan de volgende criteria:

- De negatieve controle (water) voor beide qPCR-testen is negatief of als een Cq waarde later dan 38 gemeten wordt,

- De (meegeleverde) positieve controle heeft een Cq waarde ronde de 30.

Als de test geldig is, kan het percentage aan paarden DNA berekend worden op de volgende manier:

$$
\text { Percentage paard }=22^{(\text {Cq vertebraten-Cq paard })} \times 100 \%
$$

Elke DNA-extractie is in enkelvoud getest voor elke multiplex qPCR-test. Het percentage paard is vervolgens per DNA-extractie uitgerekend en het gemiddelde van deze percentages is berekend voor het uiteindelijke percentage per monster. Het percentage per monster is dus het gemiddelde van twee percentages. 


\subsubsection{Genesig (semi-kwantitatief)}

De methode van Genesig® (Primerdesign ${ }^{\mathrm{TM}}$ Ltd.) is ontworpen op het mitochondrieel DNA van paard en dieren (universeel dier). Er wordt gebruik gemaakt van multiplex qPCR-testen; de aanwezigheid van paard en dier wordt tegelijk getest op het monster. De meegeleverde positieve controle moet positief zijn voor beide testen, anders is de test niet geldig. Voor de negatieve controle geldt het omgekeerde; deze moet negatief zijn voor de paarden qPCR-test. De resultaten worden geïnterpreteerd zoals beschreven staat in Tabel 4.3.5.1. Een " + " wil zeggen dat dier of paard gedetecteerd is, een "-" wil zeggen dat er geen dier of paard gedetecteerd is in de qPCR-test. Vervolgens wordt er beschreven wat de interpretatie van het desbetreffende detectiepatroon zal zijn.

Tabel 4.3.5.1 Interpretatie van de resultaten van de Genesig detectiemethode.

\begin{tabular}{|c|c|c|c|c|}
\hline $\begin{array}{l}\text { Paarden- } \\
\text { qPCR }\end{array}$ & $\begin{array}{l}\text { Dieren- } \\
\text { qPCR }\end{array}$ & $\begin{array}{l}\text { Positieve controle } \\
\text { (Dieren \& paarden } \\
\text { qPCR) }\end{array}$ & $\begin{array}{l}\text { Negatieve } \\
\text { controle } \\
\text { (paarden-qPCR) }\end{array}$ & Interpretatie \\
\hline- & + & + & - & Negatief resultaat \\
\hline$+/-$ & $+/-$ & + & $</=35$ & Experiment mislukt (contaminatie) \\
\hline$+/-$ & $+/-$ & + & $>35$ & $\begin{array}{l}\text { Als een monster geamplificeerd wordt met een Cq van } \\
5 \text { of meer verschil eerder dan de negatieve control, is } \\
\text { het monster positief, anders niet overeenstemmend }\end{array}$ \\
\hline- & - & + & - & Geen dier DNA gedetecteerd \\
\hline
\end{tabular}

Als de interpretatie van de monsters "Positief resultaat, percentage paard kan berekend worden en de test-gevoeligheid kan berekend worden" (eerste rij van het overzicht), wordt het percentage paard op de volgende manier berekend:

Percentage paard $=2-[($ Cq P $[$ product $]-C q$ P $[P C])-(C q A D[$ product $]-C q A D[P C])] \times 100 \%$

In de formule zijn de volgende waarden opgenomen:

$\mathrm{Cq} P$ [product] $=\mathrm{Cq}$ van qPCR test paard [product]

$\mathrm{Cq} P[\mathrm{PC}]=\mathrm{Cq}$ van qPCR test paard $[$ positieve controle]

Cq $A D$ [product] = Cq van qPCR test alle diersoorten [product]

$\mathrm{Cq} A D[P C]=\mathrm{Cq}$ van $\mathrm{qPCR}$ test alle diersoorten [positieve controle]

Als controle kan ook de test-gevoeligheid per qPCR-test bepaald worden per monster. Dit is als extra check of het berekende percentage paard wel accuraat genoeg is. Bijvoorbeeld, het berekende percentage paard in het monster op 5\% uitkomt, maar de test-gevoeligheid is $10 \%$. Dan is de uitkomst kwalitatief in plaats van kwantitatief; er is paarden DNA aanwezig, maar het werkelijke percentage is niet betrouwbaar genoeg. Er kan alleen als resultaat gegeven worden dat het minder dan $10 \%$ paarden DNA is. De test-gevoeligheid kan bepaald worden aan de hand van Tabel 4.3.5.2.

Tabel 4.3.5.2 Bepaling van de testgevoeligheid van de Genesig detectiemethode

\begin{tabular}{ll} 
Cq van qPCR-test "alle diersoorten" & Test-gevoeligheid in procent \\
$\mathrm{Cq}<19,8$ & 0,01 \\
\hline $19,8 \leq \mathrm{Cq}<23,2$ & 0,1 \\
\hline $23,3 \leq \mathrm{Cq}<26,6$ & 1 \\
\hline $26,6 \leq \mathrm{Cq}<30,0$ & 10 \\
\hline $30,0 \leq \mathrm{Cq} \leq 35,0$ & Dier-DNA is te laag voor een accurate kwantificering \\
\hline $\mathrm{Cq}>35,0$ & Dier-DNA is te laag voor de analyse \\
\hline
\end{tabular}


Elke DNA-extractie is in enkelvoud getest voor elke multiplex qPCR-test. Het percentage paard is vervolgens per DNA-extractie uitgerekend en het gemiddelde van deze percentages is berekend voor het uiteindelijke percentage per monster. Het percentage per monster is dus het gemiddelde van twee uitkomsten.

\subsubsection{RapidFinder2 (kwalitatief)}

De RapidFinder ${ }^{\mathrm{TM}} 2$ (imegen, LifeTechnologies ${ }^{\mathrm{TM}}$ ) methode die beschreven staat onder hoofdstuk 4.3.2 kan ook gebruikt worden als kwalitatieve methode. Het DNA waarop de methode gebaseerd is, is dus gelijk; mitochondrieel paarden-DNA. Ook hier wordt gebruik gemaakt van de interne positieve controle (IPC) die gelijke Cq waarden moet geven voor alle monsters om zo remming in de qPCR-test uit te sluiten. Voor de kwalitatieve bepaling wordt gebruik gemaakt van een meegeleverde positieve controle van $0,1 \%$ paarden-DNA. Gegeven is dat als de $\mathrm{Cq}$ waarde van het monster rond de drempelwaarde ligt, zal er ongeveer 0,01\% paarden-DNA aanwezig zijn. Aan de hand van deze meegeleverde positieve controle $(0,1 \%)$ wordt de Cq drempelwaarde $(0,01 \%)$ als volgt berekend:

$$
\text { Cq drempelwaarde }(0,01 \%)=3,32+\text { Cq positieve controle }
$$

Elk monster dat gedetecteerd wordt met een lagere Cq waarde dan de 0,01\% Cq drempelwaarde voor de paarden qPCR-test, wordt beschouwd als aangetoond $(+)$, elk monster dat een hogere Cq waarde heeft dan de $0,01 \%$ Cq drempelwaarde wordt beschouwd als niet aangetoond (-). Vervolgens wordt elk monster wordt op de volgende manier geïnterpreteerd (Tabel 4.3.6.1).

Tabel 4.3.6.1 Monsterresultaten interpretatie van de RapidFinder2 detectiemethode.

\begin{tabular}{ccl}
\multicolumn{2}{c}{ Mastermix paard } & Interpretatie \\
Paard & IPC & \\
\hline- & + & Geen paard DNA gedetecteerd \\
\cline { 1 - 2 }+ & + & Paard DNA is gedetecteerd \\
\hline- & - & PCR inhibitie in het monster \\
\hline+ & - & Monster met veel paard DNA \\
\hline
\end{tabular}

Verder worden de controles op de volgende manier geïnterpreteerd (Tabel 4.3.6.2).

Tabel 4.3.6.2 Controlemonsters interpretatie van de RapidFinder2 detectiemethode.

\begin{tabular}{lccl} 
Type controle & \multicolumn{2}{c}{ Mastermix Paard } & \multicolumn{1}{l}{ Interpretatie } \\
\cline { 2 - 3 } Positieve controle $\mathbf{( 0 , 1 \%}$ & Paard & IPC & \\
paarden DNA) & + & + & Verwacht resultaat \\
\hline Extractie controle & - & - & PCR amplificatie mislukt \\
\cline { 2 - 4 } & - & + & Verwacht resultaat \\
\hline $\begin{array}{l}\text { PCR negatieve controle } \\
\text { (Water) }\end{array}$ & + & + & Contaminatie in paard DNA-extractie procedure \\
\hline
\end{tabular}

Elk DNA extract is in tweevoud getest voor de qPCR-test voor paard. De gemiddelde Cq waarde is berekend per DNA extract. Vervolgens worden voor deze methode de verschillende DNA extracten van hetzelfde monster apart geëvalueerd of de Cq waarde boven of onder de 0,01\% Cq drempelwaarde valt. 


\section{$5 \quad$ Resultaten praktische vergelijking}

Het DNA dat geëxtraheerd is uit de monsters (Tabel 4.1.1) is gebruikt in de concentratie die geadviseerd wordt in de verschillende methoden en getest in enkel-, twee- of drievoudige reacties zoals voorgeschreven staat per methode.

Elke methode heeft verschillende (kwaliteits-) voorwaarden waaraan gedaan moet worden. Deze worden beschreven in hoofdstuk 2 en de resultaten van de kwaliteitsvoorwaarden zijn per detectiemethode weergegeven in Tabel 5.1.

Tabel 5.1 Overzicht van de kwaliteitsvoorwaarden van elke detectiemethode zoals negatieve controles en standaardlijn.

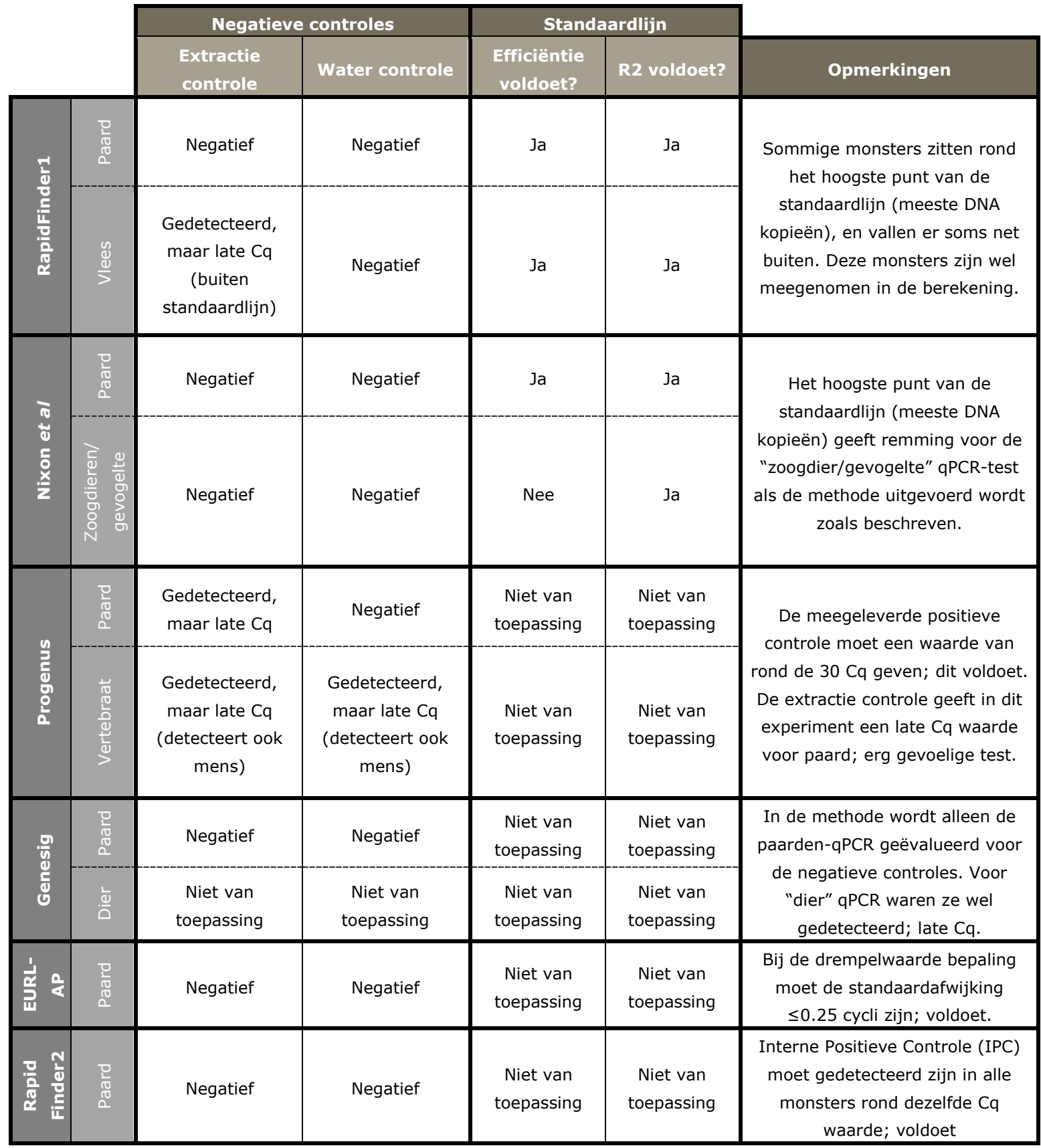


De extractie-controle behoort negatief te zijn, maar in sommige methoden is dit niet het geval. Dit wijst erop dat sommige methoden gevoeliger zijn dan andere methoden. In de methoden van Progenus en Genesig wordt de extractie-controle niet genoemd als negatieve controle, alleen water.

Alle methoden zijn in enkelvoud uitgevoerd. In Tabel 5.2 is een overzicht weergegeven van de resultaten die verkregen zijn met de verschillende detectiemethoden. RapidFinder1, Nixon et al., Progenus, Genesig en EURL-AP zijn semi-kwantitatieve detectiemethoden. De resultaten van deze testen zijn uitgedrukt in procenten als er paarden DNA gedetecteerd is, conform de methode, of negatief als er geen paarden DNA gedetecteerd is. In het geval van de EURL-AP methode wordt het resultaat uitgedrukt in meer of minder dan $1 \%$ paardenvlees aanwezig ( $>1 \%$ of $<1 \%$ respectievelijk). Als een monster in het ene DNA-extract meer dan $1 \%$ paardenvlees aantoont en in het andere DNAextract minder dan $1 \%$ paardenvlees, is het resultaat onbeslist en wordt hier weergegeven als $\langle 1 \%\rangle$. RapidFinder2 is een kwalitatieve methode. De resultaten zijn uitgedrukt in aangetoond/niet aangetoond/ negatief. Aangetoond wil zeggen dat er paarden DNA aangetoond is en boven de drempelwaarde gedetecteerd is, niet aangetoond wil zeggen dat er wel paarden DNA aangetoond is maar deze Cq waarden onder de drempelwaarde zijn gedetecteerd, negatief wil zeggen dat er geen paarden DNA aangetoond is.

De percentages die berekend zijn uit de detectiemethoden worden vervolgens geclassificeerd als kleiner of groter dan $1 \%$ paardenvlees. Wanneer deze classificatie overeenkomt met de resultaten van de EURL-AP referentiemethode, is het percentage in groen weergegeven in de tabel. Als dit niet overeenkomt met de referentiemethode, is het percentage in rood weergegeven.

Tabel 5.2 Overzicht van de resultaten verkregen uit de verschillende detectiemethoden. Per methode zijn er acht verschillende vleesmengsels getest, volgens de voorgeschreven instructies van de corresponderende methode. EURL-AP, RapidFinder1, Nixon et al., Progenus en Genesig zijn semikwantitatieve methoden, het resultat is gegeven in procenten als er paarden DNA gedetecteerd is of negatief als paarden DNA niet gedetecteerd is. RapidFinder2 is een kwalitatieve methode, het resultaat is gegeven in aangetoond/niet aangetoond/negatief. In groen en rood is weergegeven of het resultaat van de methode respectievelijk wel of niet overeenkomt met het resultaat van de EURL-AP referentiemethode.

\begin{tabular}{|c|c|c|c|c|c|c|}
\hline & $\begin{array}{l}\text { EURL- } \\
\text { AP }\end{array}$ & $\begin{array}{c}\text { Rapid } \\
\text { Finder1 }\end{array}$ & $\begin{array}{l}\text { Nixon } \\
\text { et al. }\end{array}$ & Progenus & Genesig & $\begin{array}{c}\text { Rapid } \\
\text { Finder2 }\end{array}$ \\
\hline \multicolumn{7}{|l|}{ Vlees-verdunningsreeks } \\
\hline $\begin{array}{l}100 \% \text { paardenvlees/ } \\
0 \% \text { rundvlees }\end{array}$ & $>1 \%$ & 103,02 & 99,95 & 105,77 & 27,48 & Aangetoond \\
\hline $\begin{array}{l}10 \% \text { paardenvlees/ } \\
90 \% \text { rundvlees } \\
\end{array}$ & $>1 \%$ & 9,36 & 18,68 & 15,60 & 2,81 & Aangetoond \\
\hline $\begin{array}{l}1 \% \text { paardenvlees/ } \\
99 \% \text { rundvlees }\end{array}$ & $<1 \%$ & 1,06 & 2,26 & 2,63 & 0,31 & Aangetoond \\
\hline $\begin{array}{l}\text { 0,1\% paardenvlees/ } \\
\text { 99,9\% rundvlees }\end{array}$ & $<1 \%$ & 0,15 & 0,14 & 0,35 & 0,03 & Aangetoond \\
\hline \multicolumn{7}{|c|}{$\begin{array}{l}\text { Andere 1\% paardenvlees } \\
\text { mengsels }\end{array}$} \\
\hline $\begin{array}{l}1 \% \text { paardenvlees/ } \\
99 \% \text { snack }\end{array}$ & $<1 \%>$ & 1,81 & 0,50 & 5,13 & 0,18 & Aangetoond \\
\hline $\begin{array}{l}\text { 1\% paardenvlees/ } \\
\text { 99\% rundvlees } \\
\text { EURL-AP }\end{array}$ & $<1 \%$ & 2,31 & 1,45 & 4,64 & 3,77 & Aangetoond \\
\hline \multicolumn{7}{|l|}{ Negatieve controles } \\
\hline $\begin{array}{l}0 \% \text { paardenvlees/ } \\
100 \% \text { rundvlees } \\
\end{array}$ & Negatief & Negatief & 0,00 & 0,00 & 0,00 & Negatief \\
\hline $\begin{array}{l}\text { 0\% paardenvlees/ } \\
100 \% \text { snack }\end{array}$ & Negatief & Negatief & Negatief & Negatief & Negatief & Negatief \\
\hline
\end{tabular}

Groen: resultaat komt overeen met EURL-AP referentiemethode; rood: resultaat verschilt van EURL-AP referentiemethode. 
Alle methoden voldoen aan de kwaliteitseisen, met uitzondering van de methode van Nixon et al [5] waarbij de efficiëntie van de qPCR niet voldoet aan de eisen (zie Tabel 5.1). In de omschrijving van deze detectiemethode staat dat als de standaardlijn niet voldoet aan de eisen, dat het experiment herhaald moet worden. Echter, doordat er duidelijk remming aanwezig is bij het hoogste punt van de standaardlijn (waar de meeste DNA kopieën inzitten), zal een herhaling van het experiment alleen zinvol zijn als er minder DNA gebruikt zal worden voor de standaardlijn en ook voor de monsters. De percentages van Nixon et al. die in Tabel 5.2 staan, zijn de percentages die verkregen zijn zoals de methode voorgeschreven staat, ook al voldoet de standaardlijn niet aan de gestelde eisen.

In de negatieve controles, $100 \%$ rundvlees en $100 \%$ snack, is paard niet gedetecteerd of in hele kleine hoeveelheden $(<0,00 \%)$. Een verklaring voor de hele kleine hoeveelheden paard dat aangetoond is in het rundvlees, kan veroorzaakt worden door niet specifieke amplificatie van de qPCR-test of door(onbedoelde) verontreiniging. Niet specifieke amplificatie wil zeggen dat de paarden qPCR-test ook rund aantoont na een aantal (veel) cycli. De qPCR-testen om zoogdier/gevogelte, vertebraat of dier aan te tonen, waren inderdaad gedetecteerd in deze negatieve controle monsters; er is inderdaad dier DNA aanwezig. Verontreiniging kan voorkomen door bijvoorbeeld niet goed schoonmaken van het materiaal bij het maken van de mengsels. Als de testen gevoelig genoeg zijn, hoeft er maar slechts één cel van paardenvlees achter te blijven en wordt deze al gedetecteerd.

De EURL-AP referentie methode is uitgevoerd zoals voorgeschreven, inclusief de Cq drempelwaarde bepaling. Vervolgens is er per monster gekeken of deze de $1 \%$ drempelwaarde overschreden heeft of niet (Tabel 5.2). Zoals verwacht, hebben de $100 \%$ en $10 \%$ paardenvlees mengsels deze drempelwaarde overschreden, dat wil zeggen de Cq waarden van deze monsters vóór de Cq waarde van de drempelwaarde zijn. De $1 \%$ paardenvlees in rundvlees monsters (zowel van het de vleesverdunningsreeks als de officiële standaard van het EURL-AP) hebben beide niet de drempelwaarde overschreden in dit experiment, maar deze monsters zijn wel gedetecteerd met een hogere $\mathrm{Cq}$ waarde dan de drempelwaarde. Alleen de $1 \%$ paardenvlees in snack heeft een onbeslist resultaat $(<1 \%>)$. Als bij een herhaling van de qPCR-test blijkt dat het monster weer een onbeslist resultaat geeft, zal deze gerapporteerd worden als minder dan $1 \%$ paardenvlees aangetoond.

De kwalitatieve methode van RapidFinder2 is een methode die potentieel gebruikt kan worden voor de toepassing of er verontreiniging van paardenvlees aanwezig is. Bij deze methode wordt vermeld dat als een monster rond de meegeleverde drempelwaarde ligt, dat er waarschijnlijk ongeveer 0,01\% paarden-DNA aanwezig is. Als deze drempelwaarde toegepast wordt zijn inderdaad alle paardenvlees mengsels aangetoond. De negatieve controles zijn niet aangetoond, zoals verwacht. 


\section{Discussie en conclusie praktische vergelijking}

\section{Bevindingen}

Met de vier geselecteerde semi-kwantitatieve methoden is in alle vleesverdunningsmonsters paardenDNA aangetoond en de percentages zijn berekend (Tabel 5.2). De percentages komen bij sommige methoden beter overeen met de werkelijke percentages dan bij andere methoden. Een mogelijke verklaring hiervoor is dat de data-analyse per methode verschilt. Het is belangrijk te vermelden dat de methoden allemaal slechts één keer zijn uitgevoerd. Er is dus niet onderzocht of de waardes bij herhaling hetzelfde zijn. Dit viel buiten de scope van het huidige project. De percentages die verkregen zijn door methoden waarbij gebruik gemaakt wordt van een standaardlijn (RapidFinder 1 en Nixon et al.) komen in dit experiment het beste overeen met het werkelijke percentage, ondanks dat de standaardlijn van de Nixon et al. methode niet geheel voldoet aan de gestelde criteria. Om de standaardlijn van Nixon et al. te verbeteren in eventuele vervolgexperimenten, zal er minder DNA gebruikt kunnen worden om zo de remming in de qPCR-test te verminderen. Een andere optie is om de punten met de hoogste concentratie in de standaardlijn uit de analyse te halen. Hierdoor komen een aantal monsters buiten de standaardlijn te liggen en kunnen daarom niet conform de methode gekwantificeerd worden. Dit zal ook het geval zijn als de concentraties van het DNA van de standaardlijn verlaagd worden, en de hoeveelheid DNA van de monsters gelijk zal blijven.

De kwalitatieve methode RapidFinder2 geeft in dit experiment tegenstrijdige resultaten in vergelijking met de EURL-AP referentiemethode voor alle monsters die $\leq 1 \%$ paardenvlees bevatten (aangetoond, terwijl de EURL-AP methode niet aangetoond geeft als uitslag). RapidFinder2 is namelijk een methode waarbij een lagere drempelwaarde gesteld wordt en het daardoor is het een extra gevoelige detectiemethode die eerder resulteert in een positieve uitslag.

Of de $1 \%$ drempelwaarde van de referentiemethode van het EURL-AP overschreden wordt door de semi-kwantitatieve methoden, is weergegeven in Tabel 5.2 met de kleuren rood en groen. Groen wil zeggen dat het resultaat van de geteste detectiemethoden overeenkomt met de referentiemethode, rood wil zeggen dat het resultaat niet overeenkomt.

Geen van de kwantificeringsmethoden geven exact hetzelfde resultaat (groter of kleiner dan de $1 \%$ drempelwaarde) als de EURL-AP referentiemethode. Het mengsel van de vleesverdunningsreeks dat $10 \%$ paardenvlees bevat, bevat volgens de EURL-AP referentiemethode inderdaad meer dan $1 \%$ paardenvlees. Hetzelfde is bevonden voor de $100 \%$ paardenvlees. Het $1 \%$ paardenvleesmengsel van deze reeks bevat volgens de referentiemethode minder dan $1 \%$ paardenvlees. Voor één van de onderzochte methoden komen deze bevindingen overeen. Namelijk de methode van Genesig. Als de EURL-AP referentiemethode buiten beschouwing gelaten wordt en alleen de berekende percentages van de onderzochte methoden beoordeeld worden, zijn de percentages verkregen door de methode van RapidFinder het meest vergelijkbaar met het daadwerkelijk gemengde percentage gebaseerd op gewicht.

Samengevat, wanneer er een monster met hetzelfde percentage geanalyseerd wordt door verschillende methoden, komt er bij elke methode een ander percentage uit. Dit heeft te maken met de basis waarop de methode is ontwikkeld en hoe de data-analyse bij de respectievelijke methoden gedaan wordt.

Wanneer de $1 \%$ paardenvlees mengsels met elkaar vergeleken worden, zijn er onderling verschillen binnen dezelfde methode (Tabel 5.2). Deze verschillen worden veroorzaakt doordat de mengsels gemaakt zijn met verschillende vleessoorten. Met uitzondering van het paardenvlees in het snackproduct-mengsel, dit is hetzelfde paardenvlees als gebruikt is in de het vleesverdunningsreeks. Toch zijn de percentages niet gelijk aan elkaar. Een mogelijke verklaring voor dit verschil is dat het vlees waarmee het paardenvlees gemengd is, niet gelijk is aan elkaar. Het matrix effect is hierdoor zichtbaar geworden. Het DNA in het mengsel is verschillend doordat het mengsel bestaat uit andere diersoorten (in het geval van het snackproduct) en ander rundvlees. Doordat het aantal mitochondriën verschilt per diersoort en per weefsel, is er ook verschil in de hoeveelheid amplificeerbaar DNA. 
Hetzelfde gaat op voor de methode die gebaseerd is op nucleair DNA. Het percentage berekenen aan de hand van DNA kopieën is geen goede afspiegeling van de verhouding op gewichtsbasis. Omdat 1 gram van de ene diersoort/het ene weefsel niet hetzelfde aantal DNA kopieën bevat als 1 gram van de andere diersoort/het andere weefsel. Met een mengsel van meerdere diersoorten wordt deze meetonzekerheid meer vergroot.

In andere woorden, als verschillende monsters met hetzelfde percentage geanalyseerd worden door één detectiemethode, kunnen de percentages per monster verschillen. Dit wordt veroorzaakt door het matrix effect: de juiste bepaling van aantal DNA kopieën in een bepaalde hoeveelheid product van verschillende aard is (nog) niet mogelijk. Ook kan er remming optreden in de qPCR-test door de aanwezigheid van bepaalde stoffen in de productmatrix waardoor de reactie niet efficiënt kan verlopen. Hierdoor kunnen ook kwalitatieve methoden andere resultaten geven voor hetzelfde monster. De EURL-AP referentiemethode maakt gebruik van een vooraf te bepalen verdunningsfactor om zo de remming in de qPCR-test zo veel mogelijk te beperken. Dit is echter niet toepasbaar op alle mengsels van vlees.

\section{Conclusies}

Het uitgangspunt voor handhaving van de regelgeving is de $1 \%$ paardenvleesmengel EURL-AP referentiestandaard in combinatie met een mitochondriële qPCR-methode. Uit de resultaten valt op te maken dat de andere methoden bij percentages van $10 \%$ redelijk in lijn met deze methode presteren, maar juist in het kritische gebied rond de $1 \%$ heeft een afwijking gevolgen voor de conclusie of het monster wel of niet meer dan $1 \%$ paardenvlees bevat.

In dit rapport zijn semi-kwantitatieve en kwalitatieve methoden voor de bepaling van het percentage paardenvlees in vleesmengsels vergeleken met de EURL-AP-methode, die is ontwikkeld voor handhaving van de Europese regelgeving. Bij deze vergelijking is gebleken dat de overige methoden vergelijkbare resultaten geven als de EURL-AP-methode, maar dat er verschillen te zien zijn in percentages rondom de $1 \%$. Er zijn geen vals positieve resultaten gevonden met de verschillende methoden op basis van de negatieve monsters. Positieve resultaten zullen dus in de meeste gevallen daadwerkelijk wijzen op vermenging van vleessoorten. In het specifieke geval van de vermenging van paardenvlees in een vleesmengsel kunnen de resultaten (aangetoond dan wel niet aangetoond) verschillen van de EURL-AP-methode wanneer het percentage rond de $1 \%$ ligt, waarbij het erop lijkt dat de overige methoden een beperkte overschatting van het percentage paardenvlees laten zien, maar dit kan op basis van de beperkte serie niet met zekerheid worden vastgesteld. 


\section{$7 \quad$ Voorbeelden van factoren die de uitslag van een DNA test kunnen beïnvloeden}

- Te onderzoeken product

- Door verhitting kan het DNA beschadigd raken. Hierdoor kan de amplificeerbaarheid van het DNA minder worden. Bijvoorbeeld: bij een DNA test met DNA uit een 1:1 mengsel van verhit paardenvlees en onverhit rundvlees kan relatief minder paarden DNA aanwezig lijken te zijn.

- Als een product ook melk bevat dan zal het DNA in de melk ook kunnen worden gedetecteerd.

- In zure voedingsmiddelen (bijvoorbeeld cola) kan het DNA (van alle componenten) worden afgebroken, waardoor DNA analyses niet mogelijk is.

- Als een product weinig vlees en veel plantaardig materiaal bevat dan zal het geëxtraheerde DNA ook voornamelijk plantaardig DNA en relatief weinig dierlijk DNA bevatten. Als een DNA percentage berekend wordt van bijvoorbeeld paardenvlees ten opzichte van het totale DNA dan kan dit laag uitvallen, terwijl het percentage als het berekend wordt ten opzichte van de hoeveelheid rundvlees hoog kan zijn.

- Monstername

- De monstername moet zorgvuldig plaatsvinden om een representatief monster te kunnen analyseren.

- Het laboratorium kan een uitspraak doen over het ontvangen en geteste monster maar niet over de hele partij waaruit het monster is genomen.

- Monstervoorbereiding

- Om een homogeen monster te krijgen is het veelal van belang het monster in zijn geheel fijn te malen en hieruit een deel te nemen voor de DNA extractie.

- DNA analyse

- Testen gebaseerd op kern (nucleair) DNA zijn geschikter voor kwantificeren dan mitochondriële DNA testen, een percentage op DNA basis is niet in alle gevallen hetzelfde als een percentage op gewichtsbasis.

- Nucleaire DNA testen zijn minder gevoelig dan mitochondriële DNA testen en daardoor minder geschikt voor verwerkt materiaal.

- De DNA analyse dient bevestigd te worden (minimaal duplo analyse) voordat een uitslag gegeven wordt.

- Bepaling van het percentage van een diersoort in een andere diersoort

- Betrouwbare kwantificering op gewichtsbasis is nog niet mogelijk.

- Het lijkt mogelijk met nucleaire DNA testen een percentage op DNA basis te bepalen met ijklijnen gemaakt van paardenvlees in rundvleesmengsels. Ook hier is de vertaling van percentage paard in rundvlees op DNA basis naar een percentage op gewichtsbasis niet eenvoudig.

- Mitochondriële testen zijn niet geschikt voor betrouwbare kwantificering omdat verschillende weefsels verschillende hoeveelheden mitochondriën bevatten. Zo bevat vet minder mitochondriën dan vlees.

- De mitochondriële EURL-AP paarden test geeft een semi-kwantitatieve uitslag. De test is positief als het signaal eerder opkomt dan een $1 \%$ standaard van paardenvlees in rundvlees. Bij een vleesmonster betekent dit dat er ongeveer $1 \%$ paardenvlees in zit, of meer. NB Deze grenswaarde van $1 \%$ geldt alleen voor paardenvlees gemengd in rundvlees.

- Rapportage

- Het is belangrijk om bij de rapportage ook uitleg te krijgen over de achtergronden van de uitgevoerde analyse, met name de hierboven genoemde punten. 


\section{Literatuur}

1. Ballin, N.Z., F.K. Vogensen, and A.H. Karlsson, Species determination-Can we detect and quantify meat adulteration? Meat science, 2009. 83(2): p. 165-174.

2. Europees parlement en raad van de Europese Unie, Richtlijn 2000/13/EG van het Europees parlement en de raad van 20 maart 2000 betreffende de onderlinge aanpassing van de wetgeving der lidstaten inzake de etikettering en presentatie van levensmiddelen alsmede inzake de daarvoor gemaakte reclame, 2000/13/EG, Editor. 2000. p. 109/29-109/42.

3. Europese Unie, (2013/99/EU) Aanbeveling van de commissie van 19 februari 2013 betreffende een gecoördineerd controleplan ter opsporing van frauduleuze praktijken bij handel in bepaalde levensmiddelen. 2013. p. 48/28-48/32.

4. Europese Unie, (2014/180/EU) Aanbeveling van de commissie van 27 maart 2014 betreffende een tweede gecoördineerd controleplan ter opsporing van frauduleuze praktijken bij de handel in bepaalde levensmiddelen. 2014. p. 95/64-95/68.

5. Nixon, G.J., T.M. Wilkes, and M.J. Burns, Development of a real-time PCR approach for the relative quantitation of horse DNA. Analytical Methods, 2015. 7(20): p. 8590-8596.

6. Druml, B., et al., A novel reference real-time PCR assay for the relative quantification of (game) meat species in raw and heat-processed food. Food Control, 2016.

7. López-Andreo, M., et al., Identification and quantitation of species in complex DNA mixtures by real-time polymerase chain reaction. Analytical biochemistry, 2005. 339(1): p. 73-82.

8. Burns, M., et al., Measurement issues associated with quantitative molecular biology analysis of complex food matrices for the detection of food fraud. Analyst, 2016. 141(1): p. 45-61.

9. Europese Unie, Verordening (EU) Nr. 691/2013 van de commissie van 19 juli 2013 tot wijziging van Verordening (EG) nr. 152/2009 wat de bemonstering en analysemethoden betreft (Voor de EER relevante tekst). 2013. p. 197/1-197/12.

10. Pabinger, S., et al., A survey of tools for the analysis of quantitative PCR ( $P P C R$ ) data. Biomolecular Detection and Quantification, 2014. 1(1): p. 23-33.

11. Floren, C., et al., Species identification and quantification in meat and meat products using droplet digital PCR (ddPCR). Food chemistry, 2015. 173: p. 1054-1058.

12. Robin, E.D. and R. Wong, Mitochondrial DNA molecules and virtual number of mitochondria per cell in mammalian cells. Journal of cellular physiology, 1988. 136(3): p. 507-513.

13. Food Standard Agency (FSA) Report by Steve Wearne; Director of Policy, Setting a threshold for contamination of processed meat products with undeclared meat species. Open board - 21 january 2014, 2014.

14. European Union Reference Laboratory for Animal Proteins in feedingstuffs (EURL-AP), Use of the EURL$A P$ reference material to check the $1 \%$ level threshold of horse meat in beef. With respect to recommendation 2014/180/EU.

15. Hellemans, J., et al., qBase relative quantification framework and software for management and automated analysis of real-time quantitative PCR data. Genome biology, 2007. 8(2): p. 1.

16. Livak, K.J. and T.D. Schmittgen, Analysis of relative gene expression data using real-time quantitative PCR and the 2- $\triangle \triangle C T$ method. methods, 2001. 25(4): p. 402-408.

17. Pfaffl, M.W., Quantification strategies in real-time polymerase chain reaction. Quantitative Real-time PCR in Applied Microbiology, 2012: p. 53.

18. European Union Reference Laboratory for Animal Proteins in feedingstuffs (EURL-AP), Detection of horse $D N A$ using real-time PCR, Walloon Agricultural Research Centre, Editor. 18.02.2013. 


\section{Bijlage 1 Uitgebreide uitleg qPCR}

In deze bijlage wordt het proces van een qPCR-test stap voor stap uitgelegd.

Een qPCR-test maakt gebruik van drie gesynthetiseerde stukjes DNA (zogeheten de forward- en reverse primer en de probe) die specifiek ontworpen zijn op het DNA van bijvoorbeeld een bepaalde diersoort. De probe is een stukje synthetisch DNA met daaraan, in tegenstelling tot de primers, twee labels; een fluorofoor (geeft fluorescentie) en een quencher (dooft de fluorescentie). Zolang deze beide labels aan de probe zitten, zorgt de quencher ervoor dat de fluorofoor gedoofd wordt en geen fluorescent signaal geeft. Door deze eigenschap is de probe essentieel voor een qPCR-test, waarbij de toename van de fluorescentie gemonitord wordt. Dit monitoren kan gedaan worden met behulp van een qPCR apparaat: een thermal cycler. Naast de primers en de probe zijn er ook nog nucleotiden (de bouwstenen van het DNA, T, A, C, G), polymerase (enzym) en nog andere componenten aanwezig in een qPCR-test. Het startingsmateriaal, het DNA van een bepaalde diersoort, is over het algemeen dubbelstrengs (dsDNA). Omdat de primers en probe niet kunnen binden op dsDNA, moet het DNA eerst enkelstrengs (ssDNA) gemaakt worden. Het maken van ssDNA is de eerste stap in de qPCR test; de denaturatie van het DNA door middel van verhitten (Stap 1, denaturatie).

\section{Stap 1, denaturatie}

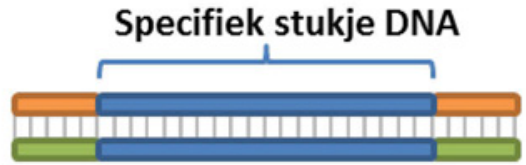

(1 kopie)
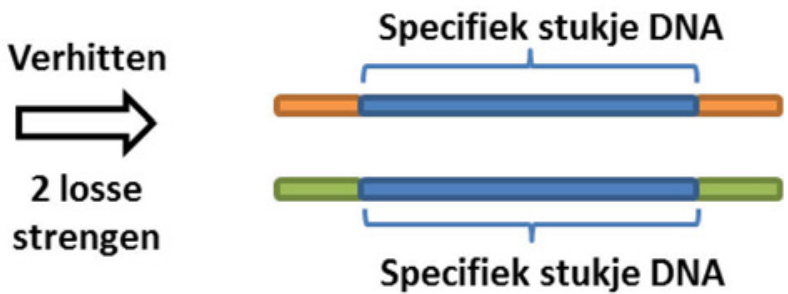

De tweede stap van de qPCR-test is het binden van de primers en probe aan het SsDNA. Hoe de primers en probe gelokaliseerd zijn op het DNA is te zien in Stap 2, binding van de primers en probe. De primers binden apart aan één van de twee DNA strengen en de probe bindt aan dezelfde streng van de forward of de reverse primer; in dit voorbeeld aan dezelfde DNA streng als de forward primer.

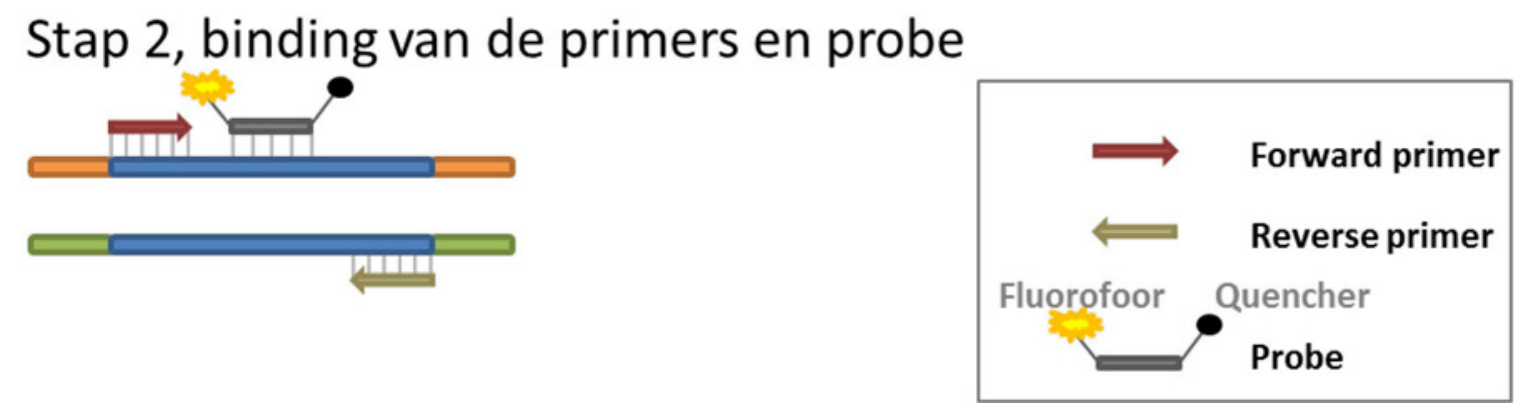

De volgende stap is het verlengen van het DNA (Stap 3, verlenging van het DNA). Dit wordt gedaan door middel van een enzym, de polymerase. De polymerase heeft een speciale eigenschap die ervoor zorgt dat het DNA verlengd wordt met vanaf de primers door middel van nucleotiden. De probe, die aan dezelfde streng zit als de forward primer, wordt ook vervangen wordt door de nucleotiden die voor de verlenging van het DNA zorgen. Bij het loskomen van het DNA wordt de probe in kleine stukjes geknipt, ook door de polymerase. Zo worden de fluorofoor en de quencher van elkaar gescheiden en 


\section{Stap 3, verlenging van het DNA}
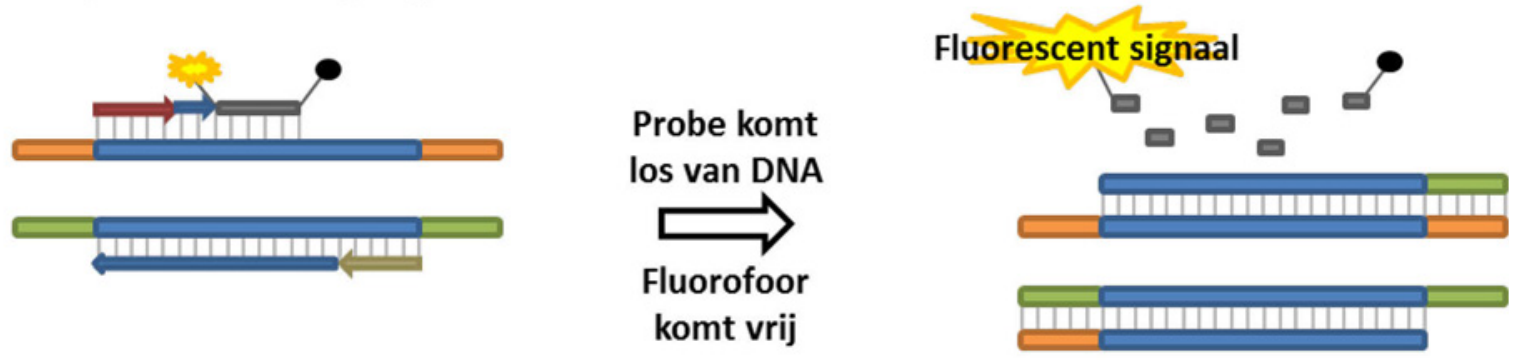

Stap 1-3 wordt ook wel 1 cyclus genoemd van een qPCR-test. Omdat er nu weer dsDNA gevormd is, moet deze weer eerst SsDNA gemaakt worden zodat de primers en probe hun werk weer kunnen doen. Stap 1-3 wordt opnieuw uitgevoerd en elke cyclus wordt het specifieke stukje DNA verdubbeld. Het vermeerderen van de kopieën wordt exponentieel uitgevoerd en binnen een paar uur worden er miljoenen identieke DNA kopieën geproduceerd (Stap 1-3 herhalend). Hierdoor neemt ook de fluorescentie exponentieel toe. Dit fluorescente signaal wordt gemeten door de thermal cycler en weergegeven in een grafiek. In de grafiek wordt het fluorescente signaal (RFU) uitgezet tegen het aantal cycli.

\section{Stap 1-3 herhalend}

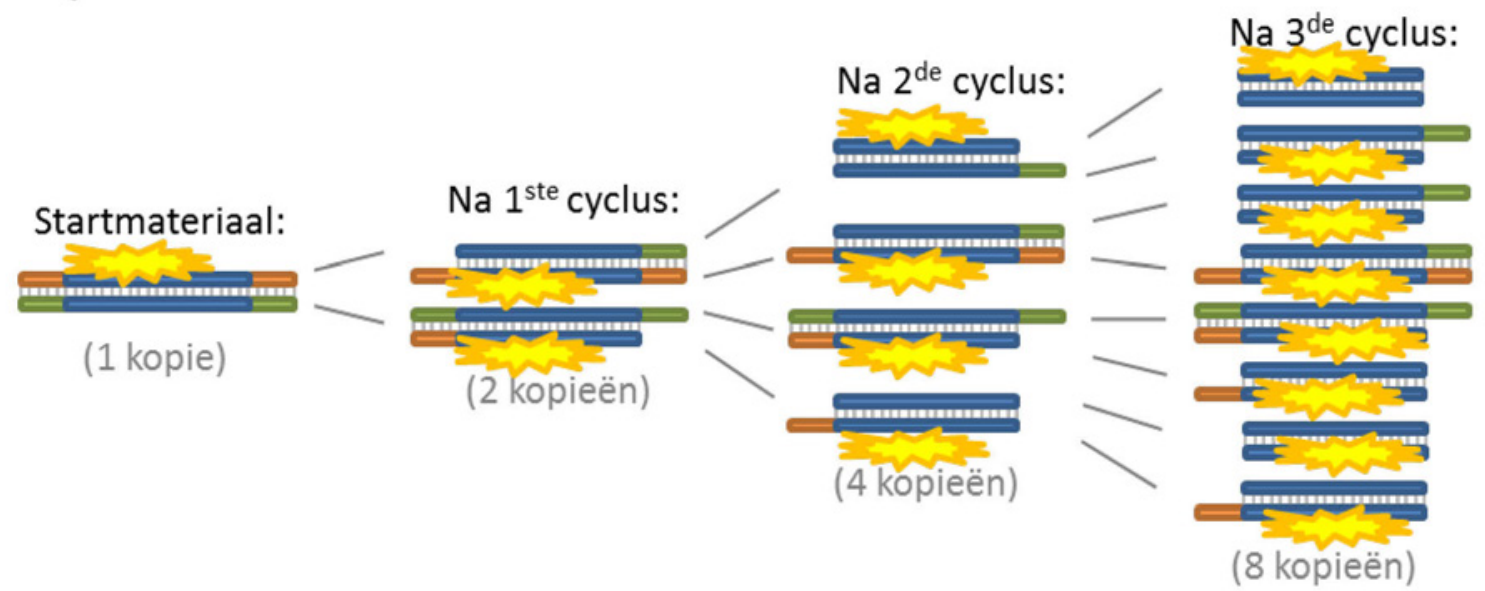

Voor een beeldende weergave over hoe een qPCR test werkt, zie het volgende filmpje:

GMO RIKILT, by RIKILT Wageningen University \& Research

https://youtu.be/B8×213xaEpQ 
RIKILT Wageningen University \& Research Postbus 230

6700 AE Wageningen

T 0317480256

www.wur.nl/rikilt

RIKILT-rapport 2017.009
De missie van Wageningen University \& Research is 'To explore the potential of nature to improve the quality of life'. Binnen Wageningen University \& Research bundelen Wageningen University en gespecialiseerde onderzoeksinstituten van Stichting Wageningen Research hun krachten om bij te dragen aan de oplossing van belangrijke vragen in het domein van gezonde voeding en leefomgeving. Met ongeveer 30 vestigingen, 5.000 medewerkers en 10.000 studenten behoort Wageningen University \& Research wereldwijd tot de aansprekende kennisinstellingen binnen haar domein. De integrale benadering van de vraagstukken en de samenwerking tussen verschillende disciplines vormen het hart van de unieke Wageningen aanpak. 



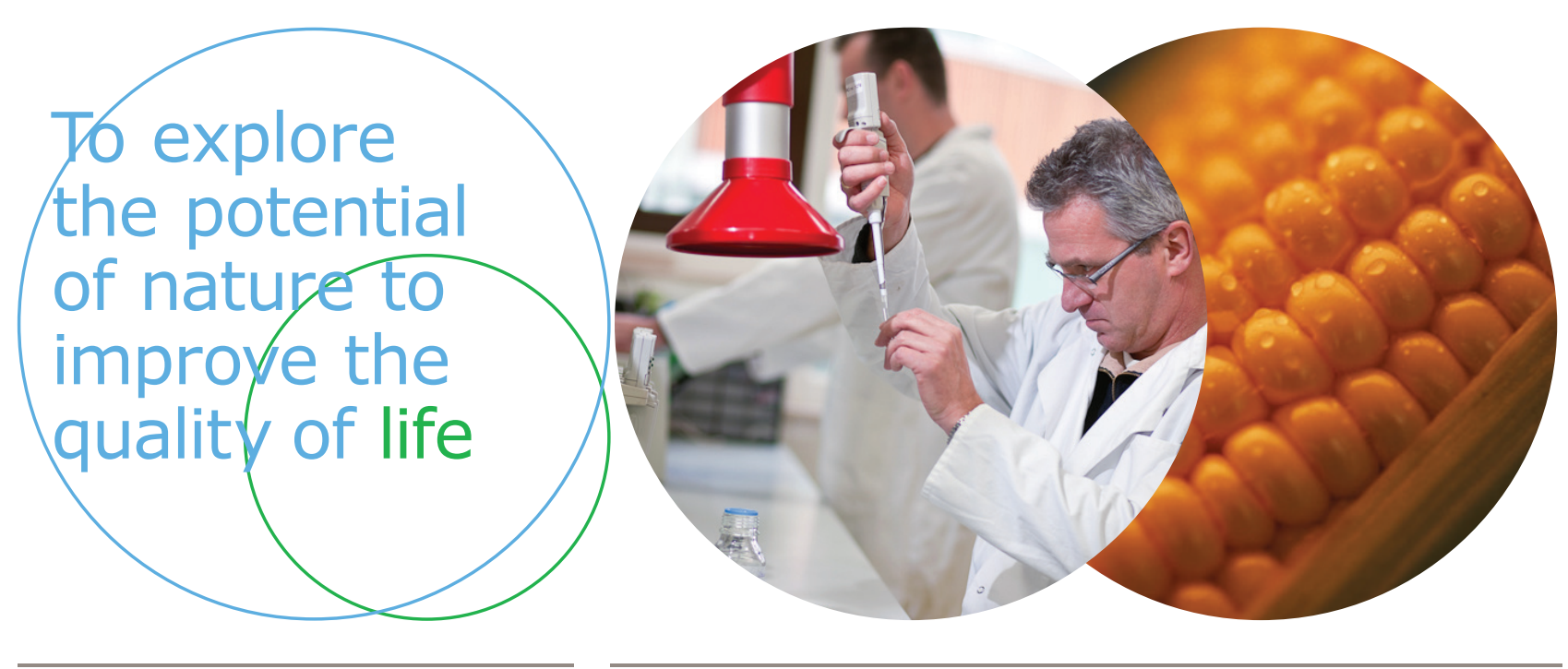

RIKILT Wageningen University \& Research Postbus 230

6700 AE Wageningen

T 0317480256

www.wur.nl/rikilt

RIKILT-rapport 2017.009
De missie van Wageningen University \& Research is 'To explore the potential of nature to improve the quality of life'. Binnen Wageningen University \& Research bundelen Wageningen University en gespecialiseerde onderzoeksinstituten van Stichting Wageningen Research hun krachten om bij te dragen aan de oplossing van belangrijke vragen in het domein van gezonde voeding en leefomgeving. Met ongeveer 30 vestigingen, 5.000 medewerkers en 10.000 studenten behoort Wageningen University \& Research wereldwijd tot de aansprekende kennisinstellingen binnen haar domein. De integrale benadering van de vraagstukken en de samenwerking tussen verschillende disciplines vormen het hart van de unieke Wageningen aanpak. 